Why do Governments Sell Privatised Companies Abroad?

By: Bernardo Bortolotti, Marcella Fantini and Carlo Scarpa

Working Paper Number 293

March 2000 


\title{
Why do Governments sell privatised companies abroad? ${ }^{*}$
}

\author{
Bernardo Bortolotti ${ }^{\text {[ }}$ \\ Marcella Fantini ${ }^{:}$ \\ Carlo Scarpa
}

March 2000

First draft

\begin{abstract}
This paper provides an empirical analysis of Governments' decisions to sell privatised companies on both international and domestic markets in a sample of 392 privatisations in 42 countries. Political theories of privatisation find strong support in our analyses: market oriented Governments favour domestic investors in the allocation of shares. Furthermore, the need to penetrate foreign markets and to warrant better legal protection to shareholders also appear as relevant. Significant differences emerge in OECD and non-OECD countries. In wealthy economies stock market liquidity favours cross-listing, while in emerging countries Governments resort to cross-list in order to "import" liquidity and to develop domestic stock markets. Legal institutions also play a different role. In OECD countries, weak shareholder protection induces Governments to cross-list, in order to borrow the reputation and best practices of established exchanges. On the other hand, creditors' protection is more relevant in non-OECD countries, where weak legal protection of creditors reduces the scope of bank finance, forcing Governments to look for external finance abroad.
\end{abstract}

Keywords: Privatisation, Cross-listing, International Financial Markets, Political Economy, Investor Protection

JEL Class.: L33, G15, G30, K22

\footnotetext{
* This research has been supported by Fondazione Eni Enrico Mattei, Milan. Domenico Siniscalco played an important role in the start of this project, and we gratefully acknowledge his contribution. We would like to thank William Megginson, Marco Pagano and the participants to a seminar at CIFRA, Amsterdam, for helpful comments and discussions. Fabio Merlino and especially Cristian Galizzi provided excellent research assistance. Ragui Assaad, Matteo Bugamelli, Chong Ju Choi, Fabrizio Balassone, André Léger, Gerrit de Marez Oyens, Giovanna Prennushi, and the Research Departments of the Dublin and Johannesburg Stock Exchanges, and of the MOEA (Taiwan) provided great help with data. The usual disclaimer applies.

${ }^{\S}$ University of Turin, IRES - Université Catholique de Louvain, and Fondazione Eni Enrico Mattei, Milan. Address: Fondazione Eni Enrico Mattei, Corso Magenta 63, 20123 Milan, Italy. tel: (39) 02-52036931; fax: (39) 02-52036946; e-mail: bortolotti@feem.it

† University of Bergamo and Fondazione Eni Enrico Mattei, Milan - fantini@ feem.it

\# University of Brescia and Fondazione Eni Enrico Mattei, Milan - cscarpa@eco.unibs.it
} 


\section{Introduction}

Privatisation has certainly been an overriding force in financial markets development. According to recent accounts, in the last 15 years privatisation substantially contributed to the total capitalisation of world's stock markets. As of end 1998 the total market value of privatised companies was nearly 10 per cent of the world's total, boasting over onefifth of the non-US total (Megginson and Boutchkova, 1999).

In the last ten years, the massive wave of privatisations by international offerings fostered the development of global capital markets and the scope of cross-border investment (Asher, 1996). To date, the 21 largest common stock issues in history have been privatisations, and 15 of which global offerings. Furthermore, among the 650 major sales of the last ten years, about 150 involved an equity issue on non-domestic markets, yielding approximately US\$52bn Government revenue (data from Privatisation International).

Domestic financial market development is often an explicit objective of privatisation programs. In this respect, the decision to list the company in international markets appears puzzling since a fraction of equity will be allocated to foreign investors and traded abroad; however, privatised companies appear to be particularly eager to seek a foreign listing (Pagano et al., 1999).

This paper tackles this apparent puzzle, trying to answer the following questions. Why do Governments list abroad or cross-list privatised companies? Which factors could explain their willingness to sell equity on foreign markets? What are the economic, political or institutional issues at stake?

We provide some answers by examining 392 share issue privatisations in 42 countries ${ }^{1}$. First of all, we distinguish issues involving a foreign tranche - earmarked to non-domestic markets and investors - and purely domestic privatisations. This allows us to estimate the factors underlying (i) the probability of listing abroad at the privatisation stage; (ii) the percentage of privatised stock floated abroad.

The main results that we have obtained can be summarised as follows.

\footnotetext{
${ }^{1}$ We are painfully aware of the limitations of cross country analyses like the present one and of the risks one runs in such a comparative study. We hope that the benefits will prove larger than the undeniable costs.
} 
The analysis of the whole sample shows that cross-listing is a global trend, becoming more important over time as the Government acquires experience and financial markets integration advances.

The sector where the firm operates is also relevant. We find strong evidence that companies exposed to global competition are more eager to seek a foreign listing, submitting to the discipline of international capital markets. This is particularly true for telecommunications companies, which seem to have an in-built vocation towards foreign exchanges. On the contrary, Governments show much more reluctance to sell abroad shares of companies operating in the energy sector. Probably Governments are cautious when privatising "strategic" sectors and foreign investors wary of political interference.

Another aspects that emerges from our analysis is that Governments resort to international sales as a way to promote trade. A low level of inward and outward trade flows is systematically associated with a higher probability of cross-listing and with higher stakes sold to foreign investors. Tapping international financial markets is therefore considered functional to increase the penetration on foreign product markets.

The international profile of share issue privatisations has a political determinant: "right-wing" Governments are less likely to sell abroad and tend to sell a larger percentage of shares to domestic investors. The empirical predictions of the political economy of privatisation is confirmed in our data (Biais and Perotti, 1999): right-wing Governments earmark shares to domestic investors to increase the spread of ownership and to create the political support for market oriented policies.

The analysis of the global sample indicates that there might be considerable differences in two sub-samples of countries (OECD vs. non-OECD countries), and this second part of the analysis also yields interesting results. In particular, two aspects emerge. First, the global analysis contains results which are the due to one or the other group of countries, but often conceals effects of opposite signs. Moreover, some differences emerge between the decisions (i) to sell privatised companies abroad and (ii) how much equity to float. The results of this finer analysis are the following.

First of all, stock market liquidity favours cross-listing in advanced economies, while in "emerging" markets lower liquidity is what induces Governments to engage in the operation. The intuition seems to be that the location of the market where most of trading will take place is crucial. Within OECD countries, selling abroad does not change the fact that home-country bias in investors' decisions will make the home exchange the dominant one; the more liquid it is, the more likely investors are to welcome the 
privatised firm. In emerging or developing economies, the foreign market is often the dominant one, so that home market features are no obstacle to the cross-listing; in this case, the crucial factor is the desire of the Government to list its company in a more liquid market, and this is more important for countries with weak home stock markets.

Second, different legal institutions play different roles in the two sub-samples. Shareholder protection matters in OECD countries: a Government of a developed country affording weak shareholder protection cross-list more, in order to import foreign best practices and to borrow the reputation of more established exchanges. On the contrary, creditor protection matters in non-OECD countries. In less developed economies, a weak legal protection to creditors probably reduces the scope of bank finance, forcing Governments to look for external finance abroad.

Coming to political theories of privatisation, we can see that the general statement that right-wing Governments sell smaller shares of the company abroad is confirmed in all analyses. However, the non-OECD sample indicates that "right-wing" Governments in these economies are more likely to sell abroad; indeed, selling a firm to foreign investors could represent a commitment device supporting market oriented policies.

Finally, new determinants emerge in the analysis of sub-samples. In OECD countries unemployment is crucial: we find high rates of unemployment associated with a lower frequency of international sales, indicating that Government are probably fearful of the pressures to cut employment coming from foreign investors. Second, Governments in financial distress sell a large fraction of privatised equity abroad in order to maximise proceeds. Indeed, floating the company on more developed stock market should allow Governments to generate more revenue.

In non-OECD economies, a low level of foreign debt is key to target successfully foreign markets. Countries in financial distress are less able to float companies abroad; public finance variables seem to play the role of indicators of financial credibility for the country, and investors are reluctant to invest where country risk is too high.

The paper is thus mainly related to two streams of literature. The first one deals with privatisation methods - which however only seldom tackles the issue of where to sell a firm - and the second one focuses on the cross-listing by private firms.

Within the empirical literature on privatisation (see Megginson and Netter (1999) for a survey), several papers analysed the choice of the privatisation method. Megginson et al. study the choice by Governments of sale in the form of a private placement vs. floatation on public equity markets, finding that share offerings are more frequent the 
larger is the firm, when the company is a telecom, and the more developed are capital markets. Private sales are instead more likely when government' deficit is high. Bortolotti et al. (1999) confirm the importance of budget constraints in Governments' opting for direct sales, finding also a political determinant in the choice of the privatisation method: right-wing governments are associated with privatisation on public equity markets. Jones et al. (1999) in a comprehensive analysis of share issue privatisations provide descriptive evidence about the percentage of shares allocated to foreign investors. They find foreign allocation of shares in 60 per cent of the 505 initial offers reported for the 1977-97 period, with an average percentage of stock of 30 per cent. They use these percentage as an explanatory variable of underpricing, finding little significance. Although our samples partially overlap, they do not examine the determinants of the allocation of shares to foreign investors.

In the finance literature, the paper is very closely related to the work of Pagano et al. (1999) on the determinants of the cross-listing decision by private companies. They show that the probability of a cross-listing is positively related to the size on the company, to foreign turnover and high R\&D expenditure ${ }^{\text {b }}$.

The paper is organised as follows. Section 2 analyses the main issues, surveys the relevant literature and puts forward some of the hypotheses we have worked on. Section 3 presents the dataset, and illustrates in detail the variables used in our study. Section 4 provides some descriptive statistics and illustrates our main results.

\section{The determinants of the decision to cross-list}

There are very few established theoretical results that we can use to put forward hypotheses on this problem. Notice that our analysis will try and explain both (i) the decision to list abroad and (ii) the percentage of capital to place in the foreign stock market. Although these decisions are in principle separate, in abstract terms it is hard to think of variables likely to affect one side of the story, but not the other. Ex-ante, we shall not distinguish these two logical steps, and thus the considerations that follow can be referred generically to the decision to list companies abroad, without further specifications.

\footnotetext{
${ }^{2}$ Work by other authors is reviewed in the following section as their results represent the basis for some of our hypotheses.
} 
As the decisions to go public by owners of private companies and by Governments are probably related, it is interesting to start by considering why private companies crosslist.

A reason why private firms do so is that they may be unhappy with the reputation of their home stock market and try to borrow the host country's reputation, as the foreign market acts as a certification body for the company. In this way, managers of firms with high expected profitability may credibly convey their private information on future prospects of the firm by listing on a market where disclosure is higher and investor protection stricter (Fuerst, 1998, Pagano et al., 1999, Leuz and Verrecchia, 1999).

In any case, firms are keen to attract foreign capital, but several empirical studies (e.g., Lewis, 1999) confirm that a strong home country bias exists, so that investors tend to keep a "larger than optimal" share of their funds in home financial markets. Crosslisting is therefore a way for companies to diversify the sources of external finance and reduce the cost of capital.

Empirical evidence suggests that cross-listing of a share can also increase its liquidity (Karolyi, 1998). Although the concept of liquidity is intrinsically ambiguous ${ }^{3}$, it usually refers to the ability of a trader to sell or buy a stock (i) without delays (ii) at a price not subject to sudden changes related to orders of normal size and (iii) with low transaction costs. A more liquid stock is thus less risky as shareholders can sell it or buy it more promptly, with lower price volatility and/or lower bid-ask spreads.

Liquidity is thus highly desirable, and the fact that cross-listing should decrease the cost of risk capital is no surprise: an increase in liquidity entails a greater desirability of the stock from an investor's viewpoint, so that the return investors require should be lower. The evidence on the effects of cross-listing surveyed in Karolyi (1998) indicates that indeed cross-listing could be an effective way to increase the liquidity of the stock, although factors like market fragmentation could have an offsetting impact (see Domowitz et al. (1998)).

Other reasons to list on foreign markets are related to the desire of the firm to achieve a greater "visibility" to foreign customers (Karolyi, 1998). As Pagano et al. (1999) suggest, cross-list could be a strategy to capitalise on product market reputation. Indeed, high foreign sales appear to be increase the probability of cross-listing. Both private companies and SOEs which are exposed to global competition are maybe 
particularly eager to tap international capital market in order to increase penetration on foreign markets ${ }^{\text {. }}$.

\subsection{When the Government is the seller}

Although there are probably common determinants, we believe that the public $v$. private identity of the seller should matter in the decision to cross-list. In a privatisation process, a Government also pursues more general objectives that could affect the structure of the placements and the regional distribution of the offering, such as: alleviating public finance, redistribute wealth for political reasons, develop securities markets, increase institutional credibility. These are the factors that we mainly focus on the present analysis, while - also given the size of our sample - company-specific information is only marginally considered.

The possible determinants of the decision to cross-list shares of privatised companies are grouped into several categories: (i) public finance variables; (ii) external accounts variables; (iii) political variables; (iv) institutional variables; (v) stock markets development indicators; (vi) company and transaction characteristics and (vii) control variables.

(i) As to public finance, we already know that countries which have fiscal problems tend to privatise more (Bortolotti et al., 1999). Given the decision to privatise, selling a firm abroad allows one to reach a larger number of potential investors, and thus increases the expected revenue from the deal, so that countries with problems of public budget should be more likely to use this channel.

Furthermore, countries which have fiscal problems should also tend to list their companies in foreign markets to signal to the international community the effort to trim down the public debt, as a strategy to increase credibility of stabilisation and structural adjustment policies. Listing on a foreign stock market may have this effect in that the Government is trying to maximise not only the immediate quantitative result of the privatisation (namely, its current proceeds), but also the visibility of its effort.

(ii) The next aspect we want to consider is the country's openness to trade. Listing abroad is a way to provide the firm an additional international exposure and to attract foreign capital so that this decision is naturally linked to a country's relationship with the

\footnotetext{
${ }^{3}$ See Baker (1996) for a series of definitions of liquidity and of ways of measuring the liquidity of a market or of a stock.
} 
rest of the world economy, which can be specified both as regards the real side and referring to capital movements. In principle, several factors might thus prove relevant on this point, such as import, export, trade deficit and capital movements.

As specified in the previous discussion, international trade may be relevant to the cross-listing for a privately owned company as cross-listing is a way to improve the firm's ability to penetrate a foreign market. This seems to suggest that countries which are relatively open to international trade have little need to use cross-listing, while relatively closed economies will use it as a way to favour the visibility of their companies towards foreign consumers. Another element that potentially matters is the level of net capital inflows, and in principle one should expect countries with low inflows of capital to sell abroad more in order to attract (scarce) foreign capital.

It seems reasonable to expect that the presence of problems with external accounts will instead encourage countries to list companies abroad. The existence of large trade deficits or of a considerable stock of foreign debt implies that attracting foreign capital or favouring commercial penetration in foreign markets becomes particularly desirable, so that cross-listing becomes more likely.

(iii) Turning to the political economy of privatisation, it is known that right-wing Governments tend to privatise more and with the aim to create people capitalism through large share offerings on public markets and underpricing (Bortolotti et al., 1999, and Jones et al., 1999). The theoretical backing can be found in the notion of the median voter. By selling firms in the domestic market, a Government increases the voters' interest to "free-market oriented" policies and may shift the median voter's political preferences to the right. A right wing Government can thus strengthen its position by especially targeting the home market, as indicated for instance by the policy of spreading share ownership pursued by the conservative British Governments in the Eighties (Biais and Perotti, 1999).

One would therefore expect that if POs are designed by right wing Governments to target domestic voters, the right should be more reluctant to allocate shares to investors in foreign constituencies. The opposite should be true for the left, more interested - given the decision to privatise - in the maximisation of proceeds.

\footnotetext{
${ }^{4}$ For a theoretical backing of this hypothesis, see Fulghieri (1999), who suggests that the firm's presence in the foreign (goods) market improves financial markets information and thus favours cross-listing.

${ }^{5}$ One could think that the decision about the regional distribution of the offer is more technical, rather than political. In fact, in many circumstances once the book is made, if the offer is oversubscribed, the Government has to decide whether to favour domestic vs. international investors.
} 
(iv) Institutions define the playground for privatisation and may play a role in the cross-listing decision. The issue of institutional credibility mainly refers to country risk and investors protection, a point raised by an increasing empirical and theoretical literature ${ }^{6}$. On the one hand, a country where private investment is not well protected might tend to resort to cross-listing in order to borrow the reputation of another country; indeed, listing on a foreign exchange means receiving a form of certification from that exchange, so that investors know that the firm will be monitored by different markets and sets of investors ${ }^{\text {口 }}$.

Furthermore, in order to be admitted to listing on an exchange, a firm must comply to its regulations, in particular in terms of information provided to the public. For instance, listing in New York implies issuing comprehensive reports every three months, while other markets allow a much less frequent reporting. When a firm is listed in different exchanges, it automatically offers domestic investors at least the same protection offered to foreign shareholders in terms of information disclosure, and so on. This might imply that countries with little credibility or where small shareholders are less protected will tend to use cross-listing more extensively ${ }^{8}$.

(v) Turning to financial markets issues, a Government - not too differently from private firms - is interested in the efficiency of its financial market since efficient markets provide diversification, information aggregation and monitoring (Amihud and Mendelson, 1991; Holmström and Tirole, 1993). But very differently from private companies which are typically affected by co-ordination problems, a privatising Government might be able to effectively manage the externalities stemming from the listing decision (Pagano, 1993).

In this respect, it has been shown that cross-listing may also determine an improvement in the efficiency of domestic financial markets. Some empirical evidence shows that the inception of trading on the London SEAQ International section of Italian stocks actually increased the trading volume of the Milan stock exchange (Pagano and Steil, 1996). Similarly, with regards to Belgium, trading in London seems to have

\footnotetext{
${ }^{6}$ La Porta et al. (1997), (1998).

${ }^{7}$ On the relationship between privatisation processes and political risk, see Perotti and Van Oijen (1999). For the problem of law enforcement, see Modigliani and Perotti (1999).

${ }^{8}$ Potentially, there might be a second effect, in that foreign exchanges might be reluctant to accept firms coming from countries offering a low level of protection to investors. However the latter effect is probably very weak.
} 
stimulated greater trading in the home market (Anderson and Tychon, 1993) ${ }^{9}$. Crosslisting could therefore be an important tool in the transitional phase, fostering stock market development and integration. These arguments suggest therefore that the size of the stake floated on foreign markets should be negatively related to domestic financial market development, at least for countries which still need to attract the attention of foreign investors.

This should be true also because the size and efficiency of financial markets (along with savings) determines the ability of that market to easily absorb large offerings. Therefore, if a country has a large stock market its need to go abroad to look for buyers will be limited.

In principle, we should thus expect countries with small and less liquid stock markets to resort to cross-listing more than others. Governments in countries with a well developed exchange do not need to bear the costs use of a global offering, so that we could expect that liquidity indices or size indices of the stock market to be negatively related to the phenomenon we analyse. The same might be true for the savings of the country, in that if a country saves little an initial public offer will probably be harder to absorb at a reasonable price.

However, one should also consider that even if the firm is listed in different market, there typically is a "dominant" one, where most of the transactions are carried out, and which has a dominant effect on price formation. Typically, at least if the home market is reasonably developed 10 , the dominant market tends to be the home one (Karolyi, 1998), so that the quality of the home market - and in particular its liquidity becomes relevant in explaining why foreign investors may be inclined to invest their money in a given firm. In other words, firms coming from illiquid markets will be harder to sell, while firms coming from liquid markets will be more desirable to foreign investors as well.

\footnotetext{
${ }^{9}$ Notice however that these analyses compare the situation before cross-listing with the situation after it. The positive repercussion of cross-listing should thus be interpreted as an improvement relative to the previous situation. This does not imply, however, that the home market has shown an improvement relative to what would have happened if all shares had been sold in it. Thus, these empirical findings do not imply that selling shares in a foreign market is better than selling all shares in the home market; this counterfactual exercise is indeed extremely difficult and we are not aware of any evidence on this point.

${ }^{10}$ If a firm from an emerging market is quoted at NYSE, the latter market is likely to become the dominant one. Therefore, this effect is likely to be weak for countries with very small markets. Fuerst (1997) also points out the existence of relevant asymmetries of a similar type.
} 
The demand from abroad could affect the final allocation of shares as the seller adjusts it after the book-building . Essentially, having a more liquid home market shifts the international demand for shares of privatised companies to the right. This introduces an element of potential ambiguity in the sign of the coefficient of financial development indicators, in that countries with less developed markets might be less able to do crosslisting exactly because foreign investors might be reluctant to buy the firm.

It can thus be said that there is a tension between the need of a country (the need to cross-list to exploit what foreign stock markets ban offer) and the opportunities open to it (cross-listing is feasible only when the home exchange is developed enough to provide a guarantee to foreign investors). Only the empirical analysis will be able to tell which effect prevails.

(vi) Finally, the decision to cross-list should also be influenced by company's characteristics. Many stock markets are characterised by stringent requirements for listing of foreign companies, and sometimes more severe capitalisation requirements are introduced . Furthermore, the "visibility" of a company vis à vis local investors is often indicated as a factor that reduces the ability of firms to attract foreign capital: small firms only active in their home country are unlikely to be well known to foreign investors and to become widely traded abroad. Therefore, a company's size is the first aspect we can focus on, and indeed it is sensible to expect that small firms will rarely be listed in foreign markets, and that size represents a precondition for cross-listing.

The second group of variables are sector dummies, which try to capture specific sectoral features, and in particular the openness of each sector to international competition. We expect the greater international exposure of firms operating in global markets relative to firms operating in "closed", mainly national markets to make a difference. For instance, there are sectors such as telecom, where competition is intrinsically global, and where a global offer might seem quite natural; the contrary might be true for other public utilities. The reason is that information on firms operating world-

\footnotetext{
${ }^{11}$ In public offerings, the percentage of stock sold abroad is set after "bookbuilding". Under this procedure, the investment banker acting on behalf of the seller solicits bids for shares from investors and then sets the price, also adjusting the quantity supplied and the distribution of the shares among different classes of investors when closing the transaction. There have been several cases in which the percentage allocated to foreign investors increased during the bookbuilding process. For instance in Italy during the sale of the third tranche of ENI (1997) the initial offer envisaged one third of the shares reserved to international investors, while the final allocation (including the "green shoe" option) saw that percentage reduced to 27.7\%. A similar story could be referred to the sale of Banca nazionale del lavoro (1998-99), where the international share fell from an initial $34 \%$ - indicated in the offer plan - to a final value of $24.9 \%$.
} 
wide is likely to spread quite rapidly, while information on local firms remains difficult to attain for a foreign investor, who will be unlikely to but shares in firms where information lags may be substantial. Quite different is probably the case of banks, which are often regarded by Governments as "strategic" assets, especially in bank-oriented financial systems ${ }^{13}$.

(vii) The type and timing of the issue could also be important. A global offering is certainly a difficult transaction to implement. Government officials are typically assisted by economic, legal, and financial advisers in slating the enterprise for privatisation, organising the road-show, ensuring compliance with cross-border regulations, disclosing relevant information, etc. In a nutshell, the seller - suitably guided by reliable advisors has to learn how to privatise, and the experience accumulated overtime will avoid fiascos and botched sales. This argument suggests that international offerings should be less frequent and the stakes placed abroad smaller at the IPO. By the same token, international offers should be observed more often the more advanced is the privatisation process.

(viii) As for traditional macroeconomic variables, it seems natural to think that rich countries are those that are more likely to engage in sophisticated and complex financial operations, so that - at least as "controls" - some general development indicators should be considered. The level of savings and unemployment could also be considered. However, these variables will mainly be used and interpreted as control variables.

\section{Data}

Our source for data about privatisation transactions is Privatisation International Database, one of the most comprehensive sources at the company level. This source reports major deals with a cut-off value in terms of revenue of US\$500,000 from 1977 to date in 113 countries. The sample includes both public offerings (PO), and private sales. The average private sale is worth US $\$ 224.8 \mathrm{ml}$, with a median value of US\$50ml. The average PO is instead worth US\$730ml, with a median value of US\$135ml. The smallest

\footnotetext{
${ }^{12}$ As far as the NYSE is concerned, the principal listing standards are the following: 5,000 round-lot holders world-wide; 2.5 million of public shares world-wide; $\$ 100$ million of public market value.

${ }^{13}$ The notion of "strategic" sector is more common in the political debate than in the academic one. Even in the political debate there seems to be little agreement on what counts as strategic. Some Governments seem to include in the definition all utilities, and possibly heavy industry, high-tech sectors or the energy sector.
} 
PO of the sample is worth US $\$ 1,000,000$, which is the double of the cut-off. These figures suggest that by focusing on major deals we are not losing much information about privatisations on public equity markets, which are the object of our research.

Privatisation transactions by PO will be the unit of analysis. Our sample covers 392 deals in 42 of the 49 countries identified by La Porta et al. (1998) ${ }^{14}$ having at least five domestic non-financial publicly traded firms with no Government ownership in $1993^{15}$. This restriction broadly identifies countries with an existing capital market with public shareholders: this seems appropriate, in that including countries without such feature one runs the risk of mixing the decision to go abroad with the decision to have a public offer (without a proper exchange, going abroad may be the only way to run a PO). By the same token, we exclude transition or socialist economies, which would increase the heterogeneity of our sample, and which we feel should be object of a separate analysis.

Our sample contains 392 public offers, 185 of which featured a listing of stocks on foreign capital markets. In major flotations, the issues involved a cross-listing in one or more foreign market, but there are also eleven cases where the stock was only sold abroad $\frac{16}{16}$. We will not consider in the empirical analysis the regional distribution in various markets nor the various types of securities issued (ADR, GDR, or direct listings ${ }^{17}$. Not surprisingly, in the few cases where comprehensive information about the regional distribution is available, almost all the offerings involved an issue on NYSE and/or LSE.

\footnotetext{
${ }^{14}$ In our sample we have 22 OECD countries, i.e. Australia, Austria, Belgium, Canada, Denmark, Finland, France, Germany, Greece, Ireland, Italy, Japan, Korea, Mexico, Netherlands, New Zealand, Norway, Portugal, Spain, Sweden, Turkey and United Kingdom, and 20 non-OECD countries, namely Argentina, Brazil, Colombia, Egypt, India, Indonesia, Israel, Kenya, Malaysia, Nigeria, Pakistan, Peru, Philippines, Singapore, South Africa, Sri Lanka, Taiwan, Thailand, Venezuela, Zimbabwe.

${ }^{15}$ The choice of the year is appropriate to our end since 1993 is the median year of the distribution of global privatisation proceeds.

${ }^{16}$ The main case of this type one is the sale of VSNL - an Indian TLC company - which in 1997 yielded US\$439.22 m.

${ }^{17}$ When a company decides to launch a public offer of sale on a large international market, it must prepare a Depository Receipt (DR) Program. DRs a representative securities held in deposit by the country of the issuing company. They are traded in the currency of the host country and subject to its rules regarding clearance, settlement and the transfer of ownership. There are different types of DR entailing different levels of complexity and discipline. Global Depository Receipts (GDR) are usually traded in major bourses outside of the U.S. - above all on the London Stock Exchange (LSE) - and over-the-counter or off markets in the U.S. A company that issues GDRs is not subject to the General Accepted Accounting Principles (GAAP) nor must it wholly abide by SEC regulations. Companies that intend to offer their shares to American institutional investors and be quoted stock markets must use American Depository Receipts (ADR). These entail the same responsibilities as American shares, ranging from GAAPs to SEC rules on transparency.
} 


\subsection{The dependent variable}

We define our dependent variable (ABROAD) as the ratio - in each privatisation deal - between privatised equity sold abroad and total equity sold. The variable thus ranges from zero to one. We include the fraction allocated through private sale to foreign investors as for instance the sale to "qualified buyers" according to the SEC Rule 144.

ABROAD is constructed for each privatisation transaction, taking therefore different values for the same firm if it is sold in multiple "tranche". This variable displays 183 positive observations in our sample (47\%). We have chosen to use the transaction rather than the firm as observation unit because offers involving multiple tranche occur over a long period of time and Government preferences and constraints typically change over time, thus affecting their decisions to cross-list.

To avoid sample selection bias, we bring into the analysis also purely domestic public offers, namely POs only targeting domestic equity markets. This allows us to focus on two conceptually different choices, i.e. whether or not to go abroad at all (trying to explain why a Government sticks to a domestic offering), and how much to sell.

We now describe the variables that we use to test the hypotheses developed in section 2 .

\subsection{The independent variables}

As stated in the introduction, we believe that to put the Governments' decision to cross-list in the right perspective one needs to enlarge the perspective adopted for private companies. In this direction, it is particularly important to bring into the analysis the state of the domestic economic, institutional, and political system at the time of the placements. Company-specific information is certainly valuable, but the overall situation of the country and of the Government at the time of the sale are probably even more important, as they determine the objective function and major constraints of the decision maker.

The possible determinants of the decision to cross-list shares of privatised companies are grouped into several categories: (i) public finance variables; (ii) external accounts variables; (iii) political dummies; (iv) institutional variables; (v) financial markets development indicators and (vi) company and transaction information, and (vii) control variables. This list includes time-varying variables dated for the year of the privatisation transaction. The only exceptions are macroeconomic control variables that have been averaged away for one country privatisation period. The reason for that choice 
is that we are interested in capturing country-specific effects and this can be done by use of relatively stable variables like GDP per capita, aggregate savings and growth rates.

We would like to stress that this has meant building a massive database on 42 countries over an interval of 22 years (1977-98), for 29 independent variables referred to 392 operations (a sum total of more than 10.000 data points, some of which are in turn averages of data of the three years before each PO). Variables and sources are described in detail in Table 1.

[Insert Table 1 about here]

(i) Public finance variables. We consider two aspects of public finance: fiscal deficits and foreign debt. We have collected historical data and taken the average over the three years prior to each $P O$ in our sample. By doing so, we obtain variables which are not affected by endogeneity problems (a potentially important issue since privatisation - typically through revenues generation - could have an impact on public finance). In particular, having a pre-determined variable for foreign debt is crucial since (i) privatisation revenues are often allocated to a fund for debt reduction; (ii) a welldesigned privatisation package contributes to the reduction of credit risk with positive effects on interest payments; (iii) public-sector debt instruments have been used in privatisation transactions typically in less developed highly indebted economies.

We have defined the variable DEFICIT as the ratio of central Government deficit to GDP, while FDEBT is the ratio of public and publicly guaranteed debt held by foreign investors to income. The only difference is that we scale the stock of foreign debt by use of GNP (income generated by factors belonging to a country) rather then GDP (income produced in the country), since we consider particularly important the capacity of residents to honour the obligations of the country.

(ii) External accounts variables. The extent of cross-border privatisation deals could be affected by the degree on "openness" of the economy. It is customary to measure openness through conventional trade variables such as imports, exports, and the sum of the two as a percentage of GNP (IMP, EXP, TRADE). These trade variables are also time-varying, being constructed as averages over the three years prior to each $P O$. We complement these "real" side variables with a typical financial variable such as the ratio of net foreign direct investment on GNP (FDI). This variable is defined as the average of the balance between inflows and outflows of foreign direct investment for a 
given country over the three years before each PO. The choice of FDI is due to the fact that it represents the most relevant and less volatile component of international financial flows (Lipsey, 1999).

(iii) Political dummy variables. Privatisation obviously has a political underpinning, but measuring the "politics" of privatisation is a difficult exercise. Our objective is to classify the political orientation of the Government which has implemented each single PO. We have preferred to focus on the Government in place at the time of the deal rather than the one that started the privatisation, as decisions on whether and how much to sell abroad are taken just before the deal, and no commitment by previous Governments seems relevant to the point.

Governments typically change after elections and coalition re-alignment frequently occur in the course of a country's privatisation process, so it is fundamental to have a set of time-varying indicators. In this direction, we have first picked from Wilfried Derksen's Electoral Web Sites four possible categories of political orientation: (i) democratic conservative (right wing), (ii) left-wing (iii) centrist and Christian-democratic and (iv) non-democratic.

Democratic conservative parties are defined as parties adhering to traditional values in combination with free-market ideology and law-and-order positions. Left-wing parties include labour, socialist, social-democratic, and communist parties. The term "non democratic" is used when a country is ruled in a dictatorial or authoritarian way; military regimes are included in this label. The category of "centrist" parties is somehow residual, and includes coalitions which cannot be clearly labelled in any of the above ways. In particular, we include here parties which are in the centre of the political spectrum without officially adhering to free market values, Christian-democratic parties and wide coalitional Governments without a clearly discernible orientation.

We then retrieved the political history for our countries from Banks et al. Political Handbook of the World $\frac{18}{18}$, identifying the incumbent Governments at the privatisation dates and attached to the political coalition supporting the Government one of the above labels through the dummies RIGHT, LEFT, CENTER, NONDEM.

(iv) The institutional variables that we use in the analysis can be classified into two groups. The first includes a measure of Government's credibility in terms of respect to private investment as reflected in the country rankings in terms risk of expropriation and 
of repudiation of contracts by the Government (CREDIB). Since privatisation has been shown to be instrumental to reputation building and credibility, we take the ranking of the country in the year before each PO. According to the International Country Risk Guide, a country where the risk of contract repudiation by the Government is high may initiate a contract modification with a foreign business because of an income drop, budget cutbacks, a change of Government, or a change in the Government's economic and social priorities. The risk of expropriation of private foreign investments encompasses outright confiscation and nationalisation. This variable ranges from 0 to 10 .

The second group includes measures for the legal protection of investor. Legal protection of investor could potentially drive the decision to float the company abroad in more regulated environment. Legal protection of investors is defined in terms of legal rules and their enforcement. The "anti-director rights" index (ANTID) legal protection that a country's company law affords against the risk of expropriation by managers. The variable takes into account the existence by law of proxy by mail, cumulative voting for directors, oppressed minority mechanisms, requirements about the deposit of shares prior to general share holders meeting, minimum percentage of shares to call for an extraordinary meeting at $10 \%$ or below, and the pre-emptive rights that can be waived only by a shareholder's vote. This variable ranges from 0 to 6 .

The creditors rights index (CREDITOR) conveys information about the bankruptcy law of a country and accounts for the existence of restrictions such as creditors consent to file for reorganisation, automatic stay on assets, special rights for secured creditors, and management stay on the reorganisation process. This variable ranges from 0 to 4 .

We are primarily interested in testing the hypothesis that cross-listing shares may substitute weak legal protection of shareholders, but creditors' right warrant also attention. Extensive legal protection of (mainly secured) creditors is typically associated with large debt markets and powerful banks (La Porta et al., 1997, Demirgüç-Kunt and Maksimovic, 1996). Poor legal protection of creditors could therefore hinder the development of domestic bank finance, forcing governments to seek investors of privatised firms abroad. As suggested by Berglof and Von Thadden (1999), creditors'

\footnotetext{
${ }^{18}$ This is considered the standard source for this type of information, and has already been used by Alesina and Roubini (1992).

${ }^{19}$ Developed by La Porta et al. (1998), this is a very standard and widely used source for this type of information, and has already been used for instance by Rajan and Zingales (1998) and Lombardo and Pagano (1999).
} 
protection should be particularly important in emerging economies, where stock markets are small and banks play a major role in project financing.

Finally, the enforcement of law index (ENFORCE) is the average grade obtained by a country in terms of bureaucratic quality and corruption according to the International Country Risk Guide. Legal rules and their enforcement determine the level of deterrence against managerial misconduct. This variable ranges from 0 to 6 .

(v) Stock market development indicators. The stage of development of capital markets should be a critical element in the cross-listing decision by Governments. The notions of financial development and of liquidity are intrinsically fuzzy, and no obvious definitions exist ${ }^{20}$. We describe the development of a capital market by use of two sets of variables, one related to market size, and the second to its liquidity.

Size related variables are the number of listed companies (LIST) and the end of year market capitalisation as a percentage of GDP (CAP). Liquidity variables are the year volume of trade as a percentage of GDP (FLOAT) and finally the traditional turnover ratio, the ratio between the year volume of trade and the end of year market capitalisation (TURNOVER). Once again, to avoid endogeneity problems all variables are dated in the year before each PO. As sources for these data we have used IFC and FIBV (Federation Internationale des Bourses de Valeurs) publications, and a few data have been directly provided by individual exchanges.

(vi) Company and transaction information. The massive size of our sample makes it very hard to obtain detailed company information, so that we have concentrated our attention to three aspects only, all covered by the Privatisation International Database. The first one is firm's "size" defined as the total market capitalisation of the firm (SIZE), obtained multiplying the first day quote of the share on the stock market by the total number of existing shares (including those still held by the seller). Due to endogeneity problems, this variable will be used only in the descriptive analysis.

The second one is the sector of activity. We have aggregated the information provided by our database in a few broad categories using dummy variables. ENERGY includes firms in the production of oil and gas or in power generation; TLC refers to telecommunication companies; UTILITY refers to other public utilities working in sectors with little exposure to competition (e.g., natural monopolies), such as water or

\footnotetext{
${ }^{20}$ See Demirgüç-Kunt and Levine (1996) and Baker (1996).
} 
public transport and it includes firms involved (also) in gas and electricity distribution; FIN includes banks, insurance companies and other financial intermediaries.

Finally, we test the "learning" hypothesis by considering two deal-specific variables: a dummy variable (IPO) which is set equal to 1 in case of an initial public offer and to 0 otherwise, and the variable TIME, which measures the number of months elapsed since the first PO reported in the company's country.

(vii) Controls will be standard macroeconomic variables. We include in this grouping the GDP per capita (GDP), as a country average during the whole privatisation period, namely from the first to the last reported PO in our sample. The variable therefore takes the same value for each observation in the same country. We use the same procedure to construct the real growth rates of GDP (GROWTH), the ratio of gross domestic savings on GDP (SAVE), and the unemployment ratio (UNEMP). The first two variables relate to the stage of economic development of the countries, and they are useful to discriminate the cross-listing behaviour of Governments in more and less developed economies.

The aggregate savings as a percentage of GDP is also useful to capture countryspecific effects in terms of domestic absorption capacity of large share offers. By the same token, the unemployment rate is not only a control, but also possibly a critical factor in the decision to list the company abroad since the discipline coming from foreign trading may threaten redundant jobs exacerbating unemployment problems.

\subsection{Descriptive analysis}

Table 2 provides some preliminary data about privatisations in our sample and some descriptive statistics at the country level. The first column reports the number of POs, which is a good measure for the extent of one country's privatisation process. It is not surprising to find UK leading the ranking by sales, while the second position of Egypt clearly indicates how the phenomenon is not purely confined to Western economies. Six countries in our sample have never resorted to global offers, while nine have always placed their POs in some foreign market.

[Insert Table 2 about here]

Looking at country averages, we can see that the share of privatised stock sold in foreign markets is never purely "ornamental". Concentrating on international deals, we 
see that when countries decided to sell abroad at all, they sold an average of $42 \%$ of the stock offered, ranging from 13\% (Japan) to 100\% (Egypt and India).

The comparison between OECD and non-OECD countries is of considerable interest. OECD countries sell abroad more often (and all countries have done at least one global offer) but the average percentage of shares offered abroad is higher in non-OECD countries. This already suggests that the decisions on whether or not to sell in foreign markets and how much to sell may be quite distinct. Furthermore, in non-OECD countries, larger companies are more likely to be floated abroad, while the opposite holds - to a smaller extent - in OECD countries.

Coming to the size of firm sold in the foreign market (see Table 3), we can in general see that countries sell abroad larger than average firms. Indeed, the aggregate figure for the whole sample and OECD - indicating the opposite - is mainly driven by one outlier, i.e. the domestic privatisation deals of NTT - the Japanese telecommunication company, the fourth largest corporation in the world in terms of market capitalisation according to FT 500 1996. NTT was sold in three different tranches for a global amount of US\$81bn, a sum entirely raised in the home market. By dropping NTT, the average firm size for domestic PO is US\$2.18bn. With this correction, our evidence is consistent with Pagano et al. (1999) result, showing that larger companies cross-list more.

[Insert Table 3 about here]

As for sectors of activity, telecommunications sticks out as the one with the largest share placed in foreign markets. This is particularly true for non-OECD countries, where $85 \%$ of the shares sold are directed abroad (although notice that the average deal involves only $18.5 \%$ of the firm). Non-OECD countries show a particular tendency to sell firms in the manufacturing and financial sectors mainly in the home market.

Utilities, operating in regulated sectors, are characterised by an interesting pattern, in that they are sold more often abroad, but the proportion of shares sold abroad is below average in both sub-samples.

If we classify privatisations according to the political orientation of Governments, it appears quite clearly that market oriented (right-wing) Governments mainly target domestic constituencies in the allocation of shares. Indeed, they display the lowest average percentage of privatised stock floated abroad. Different patterns in the 
international profile of the issues emerge when we split the sample. While in OECD countries, market oriented Governments are reluctant to choose foreign issues, and stick to very low stakes sold abroad, in non-OECD countries, they resort to international issues more often than any other type of Government. We will explore further this asymmetric behaviour in the empirical analysis.

Finally, it is interesting to see that non-democratic Governments do not display a remarkably different behaviour from the average democratic regime.

[Insert Table 4 about here]

The preliminary analysis of mean values of independent variables for international v. domestic issues (see Table 5 for the tests on means) provides further evidence, showing that international offers are associated to high levels of per-capita GDP and low levels of growth (which confirms that rich countries are particularly active in this process). Countries more open to trade (with a high ratio of total foreign trade over GDP) tend to resort less to global offers. The same is true - somehow surprisingly - for foreign debt. High deficits appear instead positively correlated to international issues.

[Insert Table 5 about here]

The breakdown between OECD and non-OECD is again very interesting. Financially distressed non-OECD economies with high levels of foreign debt to GNP and deep fiscal deficits are less likely to float companies abroad.

The role of financial markets variables is particularly intriguing. On aggregate, stock market size relative to GDP (CAP) seems to matter, in that international offers are associated with markets with high capitalisation, but this effect is much less clear in the sub-samples. On the other hand, market liquidity (FLOAT, TURNOVER) does not characterise in a significant way - in either direction - aggregate figures on domestic and international offers. However, in this case the aggregate figure seems to conceal opposite phenomena in the two sub-samples: in OECD countries international offers are associated with more liquid home markets, while the reverse is true in less developed

\footnotetext{
${ }^{21}$ However, notice that the data on foreign debt for OECD countries display several missing values, which undermine any conclusion on this variable for this group of countries.
} 
economies. We have already stressed the potentially ambiguous role of market liquidity, but we postpone further comments to the econometric analyses.

Finally, poor shareholder legal protection appears to be associated with a higher frequency of foreign issues in OECD countries, while creditor legal protection seems more relevant in non OECD countries.

The descriptive analysis has shown that our variables might have some explanatory power. Furthermore, these first statistical results suggest that the issue at stake may have very different explanations in more or less advanced economies, indicating the need for a thorough econometric analysis of sub-samples.

\subsection{Methodology of the econometric analysis}

In the empirical analysis, we estimate the factors affecting the probability of selling abroad at all, i.e. the choice between selling shares abroad when privatising a company or not, but also the determinants of the size of the stake sold in international markets.

One possibility is to run two separate estimates, a Probit analysis for the first issue and an OLS regression on positive values of our dependent variable ABROAD; however, such an estimate would be biased as the dependent variable is limited. Therefore, we opt for a sample selection model which allows us to jointly estimate both aspects we analyse.

The model we use is a generalised Type II Tobit as in Amemiya (1985, p. 385). The first equation of the model can be written as:

$$
y_{1}=X_{1} b_{1}+e_{1}
$$

where $y_{1}$ represents the "utility" of the Government of selling abroad and $X_{1}$ are the factors affecting the dependent variable. Given that this utility is unobserved, we define a new observable variable that equals 1 when the utility of the Government is beyond a critical threshold $y^{*}$ and therefore the Government decides to sell a certain percentage of privatised stock abroad, and 0 otherwise:

$$
\begin{array}{ll}
d_{1}=1 & \text { if } y_{1}>y^{*} \\
d_{1}=0 & \text { otherwise }
\end{array}
$$

The variable $d_{l}$ is the dependent variable in the equation for the choice to sell abroad or not and we will refer to this as to the PROBIT or SELECTION equation. 
Whenever the Government decides to sell abroad we observe the percentage of privatised stock sold on foreign markets. The second equation of the model we want to estimate is thus:

$$
\begin{array}{ll}
y_{2}=X_{2} b_{2}+e_{2} & \text { if } d_{1}=1 \\
\text { not observed } & \text { if } d_{1}=0
\end{array}
$$

where $y_{2}$ represents the percentage of privatised stock sold abroad (ABROAD) and $X_{2}$ the factors affecting this variable. We refer to this equation as to the REGRESSION equation. The hypotheses on the error terms are standard, i.e. we assume that they are jointly normally distributed:

$$
\left\{e_{1}, e_{2}\right\} \sim N(0, \Sigma) \text {. }
$$

We have therefore a simultaneous analysis of two aspects. The first one (i.e. the decision to sell abroad) is captured by the Probit analysis, while the second one (the percentage of privatised stock sold abroad) is carried out thorough a simple regression equation, but the first part of the model uses the information of the second part to improve the estimation of the coefficients.

As - so far - our a priori about the determinants of the first and second "step" are not different, we choose specifications uniquely on the basis of the maximum set of variables sufficiently uncorrelated with others 2 . We therefore run a basic model then adding variables of interest, and dropping variables from the basic model whenever they cause collinearity problems.

Before the analysis, we have performed Hausman tests to check for endogeneity of the explanatory variables, and we have indeed found that firm size (its market value at the moment of privatisation, SIZE) appears to be endogenous to our dependent variable. This is not surprising, and simply means that the decision to sell a firm - at least partially - on foreign markets is not neutral relative to the stock market valuation of the firm,

\footnotetext{
${ }^{22}$ Multicollinearity is a particularly serious problem in sample selection models. In this direction, we avoided using two variables in the same regression when their correlation coefficient is greater than 0.5 in absolute value.
} 
which is positively affected by this decision. Therefore, we have excluded the variable SIZE from our regressors.

\section{Econometric analysis - the complete sample}

This first part of the analysis of descriptive statistics already indicates that (i) choosing "whether or not" and "how much" to sell abroad seem to be quite different issues and that (ii) the determinants of the choice could differ in different groups of countries.

Here we begin an econometric analysis of the data, starting from an overall view given by the whole sample considered - followed in the next sections by a more detailed analysis of the two sub-samples of countries.

Although the tables present all estimates jointly, it seems better to discuss the results distinguishing between the decision to cross list and the analysis of the size of the stake sold abroad. Table 6 reports the results of the estimates using all available observations. Let us start from the first logical stage of the decision process.

[Insert Table 6 about here]

\subsection{The decision to cross-list}

Some macroeconomic variables display a considerable influence. First, high income economies are more often involved in foreign issues. Indeed, it is not surprising that we find more developed economies involved in complex transactions like privatisations on international equity markets.

Countries with high aggregate savings and greater openness to trade are less likely to sell privatised companies abroad. It is not too surprising to find also low savings associated to foreign listing, as the limited domestic saving capacity could force Governments to look for capital abroad. More interestingly, economies which are close to international trade seek more often a foreign listing, maybe to increase penetration into foreign product markets. We also find some - albeit weak - evidence that low ratios of public deficit to GDP are associated with a higher probability of a foreign listing, indicating that countries with sound public finance are more credible and therefore tap more easily foreign investors and markets. 
Our conjecture on the existence of a learning effect so that complex transactions are postponed to a more advanced stage of the privatisation process is completely confirmed in our data. International offers seldom occur at the IPO, and their frequency increases at the end of the process. Indeed, the IPO dummy is highly significant and negative, while the variable TIME which counts the distance in months from the sale and a country's first PO is positive and significant.

The international profile of the share issue privatisations has a neat political determinant: market oriented Governments not only privatise more, 23 but stick more often to domestic sales. The coefficient of the political dummy RIGHT is always negative and highly statistically significant. The idea to earmark shares to national constituencies to create political support for market oriented platforms has been purported by Vickers and Yarrow (1988) to explain privatisation in the UK and recently formalised by Biais and Perotti (1999). The empirical implication of this model is confirmed in our data.

As for sectors, companies in telecommunications are more likely to be sold abroad; the opposite trend is found for banks and financial institutions, although statistical significance is limited. The TLC dummy is always statistically significant at the $1 \%$ level. Indeed, the discipline coming from international markets could be particularly useful for companies which are exposed to global competition like TLC, as long as having thorough analyst following. The evidence on the dummy grouping banks and other financial intermediaries (FINANCE) is much weaker, but still suggestive of the idea that banks on the contrary is a more "domestic" business.

The role of financial market size and liquidity is also noteworthy. It seems that countries with bigger and more liquid financial markets are more likely to use foreign listing. The coefficient of market capitalisation is almost significant in the Probit equation ( $p$-value .14). The ratio of the value of stock market trade on GDP (FLOAT) is instead positive and highly significant 2 . Having a strong home market is probably an important condition for a successful offering on international markets, as a strong home market bias exist. Indeed, it will be interesting to whether this result survives in the

\footnotetext{
${ }^{23}$ Evidence supporting political models of privatisation can be found in Bortolotti et al. (1999), and Jones et al. (1999).

${ }^{24}$ The turnover ratio is slightly less significant. However, given that it behaves in a completely parallel way to FLOAT, we will not show the results concerning this variable.
} 
analysis of sub-samples, as "importing" liquidity has been one of the objectives for crosslisting shares of privatised companies in emerging markets.

Finally, legal rules matter; Governments in countries with weak legal protection of investors - and consequently - poor corporate governance are more eager to seek a foreign listing. The coefficients of shareholder and creditors rights (ANTID and CREDITOR) are always negative and highly significant. As some theoretical results predict (Fuerst, 1988), cross-listing shares of a privately owned firm could represent a bonding mechanism to signal the managers' commitment to maximise shareholder value. Indeed, our result confirms this theoretical prediction. Governments with weak legal investors' protection try to "import" better legislation through cross-listing, "borrowing" foreign best practices in order to avoid highly discounted fixed price offerings in low transparency environments.

\subsection{The stake sold in non-domestic markets}

The previous estimates have allowed us to identify some driving factors in the decision to cross-list. But once the decision is made, do Governments really want to have a substantial fraction of stock traded abroad or do they stick to the bare minimum? Furthermore, which factors explain the variability in stock listed abroad? We exploit our dataset to set forth some answers to these important questions.

We estimate the size of the stake placed on foreign markets by running the sample selection model for the 185 positive values of the variable ABROAD. The results are shown in the regression equation in Table 6.

One interesting feature of these results is that they are quite different from those obtained with the Probit estimation. Some determinants of the decision to cross list still have a similar impact on the size of the stake sold abroad, while others "disappear". This is only partially surprising because the decisions on whether or not to cross-list and how much equity to float abroad are related but different.

Economic development plays the same role: growth rates of GDP are significantly and negatively related the stake sold abroad, indicating that substantial cross-listing of shares is typically associated with Governments in developed and mature economies, 
which is also consistent with the statistical description of the data and with the Probit analysis $\frac{25}{\text {. }}$

Trade flows still have an impact: the variable TRADE is again significantly and negatively related to the stake sold to foreign investors. Again, TLC companies are not only more likely to floated on international markets, but also feature substantially higher stakes sold abroad ${ }^{26}$. The political determinant of privatisation is confirmed: Governments supported by right-wing coalitions appear to be reluctant to float big stakes abroad. This is in line with the literature on the political economy of privatisation, which indicates that selling at home serves the purpose of "buying consensus" and the size of the stake is obviously the crucial aspect. This privatisation strategy allows a Government to increase the probability of success of market oriented parties at future elections.

Lower percentage of privatised stock are earmarked to international markets and investors at the IPO stage. This evidence is quite consistent with the learning effect identified in the Probit analyis. Risk averse Governments stick to domestic sales at the beginning of the privatisation process and at the IPO, maybe to avoid highly discounted fixed priced offerings when the company is not know and investor uncertainty high. By the same token, they reluctantly sell high percentage of stock to international investors, who are probably less informed than domestic ones.

Finally, the shareholder rights measure (ANTID) is negatively related to the size of the stake sold abroad: legal protection of domestic minority investors contributes to sell higher stakes in privatised companies (Bortolotti et al., 1999) but it appears to be crucial also in the decision on how much to sell abroad.

Several determinants of the decision to sell abroad explain also the percentage of stock floated abroad but some important variables, such as our stock market development indicators, apparently play no role in the decision about how much to sell.

The first stage of the decision (sell abroad or not) basically entails a choice of whether or not to overcome a threshold. In this perspective, the intuition behind some of the above results can be as follows. A Government does not seem to be able to sell

\footnotetext{
${ }^{25}$ The reason why here we concentrate on growth rates rather than GDP is purely technical, as we need to have a different specifications for the two equations to satisfy the order condition.

${ }^{26}$ Telecommunications is certainly one of the sectors where privatisation has been more intense worldwide and has been accompanied by widespread de-regulation, also pushed by various international organisations. Among regulated sectors, telecommunications are now probably the most exposed to global competition and this is probably the reason why find frequent share offerings in telecommunications with a high percentage of privatised of stock floated abroad.
} 
abroad unless its stock market is sufficiently large and liquid, but after the initial decision is made, not much is gained by increasing the percentage of capital sold.

A new sector dummy (ENERGY) turns out important when estimating the stake sold abroad. Governments seem quite wary of floating large fractions of equity in the energy sector, which is often considered "strategic".

\section{An econometric analysis of sub-samples}

The stage of economic development certainly plays a role in the decision to cross list. Tables 2, 3 and 4 clearly show that different levels of per capita national income and average growth rates of GDP are associated with different patterns in the international profile of privatisation issues. Indeed, more developed economies - with high per capita income and low growth - exhibit an higher frequency of global offerings and higher stakes sold abroad. In order to better control for the heterogeneity within our sample, we break it in two sub-samples referring to OECD and non-OECD countries and replicate the empirical analysis that we carried out in the previous section. As the correlation between independent variables varies within each sub-sample, it has proven impossible to stick to common specifications in OECD and non-OECD models. As before we will start with the econometric analysis of the decision to cross-list via a Probit model and of the percentage of privatised stock abroad through a sample selection model.

\subsection{OECD countries}

Here we have 216 observations, with 69 cases of purely domestic offers and 147 cases where we observe a percentage of capital sold abroad.

Table 7 shows the results of our estimates for OECD countries.

[Insert Table 7 about here]

Several stories already illustrated in the global analysis still hold in OECD countries. Quite interestingly, even within a relatively more homogeneous sample, the level of economic development is still important in the decision to list privatised companies abroad and so are the growth rates of GDP. The learning hypothesis is again confirmed in this sub-sample, as international offers are again increasing overtime. Indeed, the coefficients of the variable TIME are still positive and highly significant. 
The political orientation of Governments is an important element in privatisation in OECD countries. The political dummy RIGHT identifying "market oriented" Governments negatively and significantly affects the likelihood and the size of a global offering. This evidence confirms the empirical validity of the political theory of privatisation within a sample of countries with well-functioning democratic institutions.

The role of competition at the global scale is also confirmed, as issues in the telecommunication sector are very likely to target foreign markets and investors.

Home market bias appears to be particularly strong in OECD countries. Stock market development - measured by the value of trades on GDP (FLOAT) - positively influences the probability of a cross-listing. Finally, shareholder protection is again a critical determinant of the decision to privatise abroad and of the size of the stake to float. The coefficient of antidirector rights is again negative and even more statistically significant, indicating the pivotal role played by shareholders in countries where financial markets are more established. Differently from the analysis of the whole sample, creditor rights do not influence the probability of an international offer, but are critical in determining the size of the stake.

However, in OECD countries the decision to cross-list is affected by two factors that were completely irrelevant in the global analysis: unemployment rates and foreign direct investments.

High unemployment rates decrease the likelihood that a company is sold abroad and the stake sold to foreign investors; domestic issues are often earmarked to insiders managers and employees - which are maybe more interested in job tenure than profitability. Foreign investors might instead force the Government to restructure and to cut redundancies, exacerbating unemployment. It is worth noticing that unemployment is particularly high in OECD countries. The difficulty of unemployment restructuring (which often entails layoffs) renders the companies less appealing to international investors so that Governments are forced to domestic sales.

A high level of foreign direct investment (FDI) increases the probability of a listing abroad. This result is surprising, as countries boasting substantial capital flows should be less eager raise finance on foreign capital markets.

Other elements seem to suggest that the two stages of our analysis refer to fairly distinct decisions. Governments financial constraints - measured by the deficit-to-GDP before the sale - appear irrelevant in the decision about where to list, but crucial in the determining the size of the stake to sell abroad. We find high deficits associated with 
higher stakes sold abroad, indicating that Governments with hard budget constraints resort to international listings as a way to maximise privatisation revenue. Indeed, sophisticated stock markets abroad - combined with strong markets abroad - are the ingradients of a successful floatation in terms of proceeds.

Analysing several variables, we can instead detect a threshold effect, as they matter in the decision of where to sell, but they appear to be irrelevant when it comes to decide how much to sell. This is particularly true as regards financial variables. Having a large and liquid stock market helps to go abroad, in that a "good" home stock market is a precondition for having a success in foreign markets, but does not change the size of the stake sold abroad. The intuition is that even with cross-listing the home market will probably remain the dominant one in terms of trading volume, so that listing in foreign markets is unlikely to be successful if the home market does not provide sufficient guarantees in terms of efficiency, price stability, etc.

\subsection{Non-OECD countries}

Here we have 176 public offers, 38 of which displaying cross-listing 27 . A striking result of this part of the analysis is that the decision to list abroad or not and the choice of the amount of stock to place on foreign markets are completely different issues in emerging economies. In many cases, the reasons underlying these choices are even opposite. Furthermore, some factors that were important in the other sub-sample are still noteworthy, but have a different bearing on the issue at stake. Table 8 presents the estimation and Table 9 summarises the main results.

[Insert Table 8 about here]

\footnotetext{
${ }^{27}$ Unfortunately some of the data on financial market size and liquidity for some African countries are still missing, so that we are unable to use more than 150 of these observations.
} 


\begin{tabular}{|l|c|c|}
\hline & $\begin{array}{c}\text { Probability of sale } \\
\text { abroad }\end{array}$ & $\begin{array}{c}\text { \% of capital sold } \\
\text { abroad }\end{array}$ \\
\hline RIGHT & + & - \\
\hline TIME & + & - \\
\hline CREDITOR & - & 0 \\
\hline ANTID & 0 & 0 \\
\hline CAP & 0 & 0 \\
\hline FLOAT & - & 0 \\
\hline DEFICIT & 0 & 0 \\
\hline FDEBT & - & - \\
\hline TLC & + & - \\
\hline CREDIB & + & \\
\hline
\end{tabular}

Table 9: Qualitative summary of the main results (prevailing signs) - nonOECD

Let us start with the role of politics. In non-OECD countries right-wing governments are more likely to cross-list, but less willing to have a large fraction of equity allocated to foreign investors. The coefficient of the political dummy RIGHT is positive in the Probit, while negative in the estimates for the percentage of stock, remaining extremely significant in both cases.

A tentative explanation is that where the market system is not well established, a market-oriented Government might tend to use foreign listing as a commitment device. Cross-listing entails enhanced transparency of firm behaviour, which is functional to the goals of a market oriented administration. When estimating the percentage of stock, the political dummy RIGHT has negative sign predicted by the theory. Even if right wing Governments are particularly interested in cross-listing as a commitment device (given the observed positive coefficient in the Probit analysis), they seem to be reluctant to float a large fraction of shares on foreign markets given their re-election concerns.

Other asymmetries emerge in the analysis of the dynamic pattern of foreign issues. The learning hypotheses is confirmed in the Probit analysis, as we find a positive and statistically significant coefficient for the variable TIME. The frequency of international offerings increases as a country's privatisation process advances. The same variable is instead negatively associated with the stake sold so that the initial issues exhibit larger percentages of stock abroad. This puzzling result could tentatively be explained in terms of credibility. At the initial stages of privatisation in emerging countries, Governments face credibility constraints. In order to signal commitment, they choose to sell big stakes 
to foreign investors. As the process advances, Governments gain credibility overtime, allowing them to increase the frequency of international sales and to earmark shares to domestic investors to create political support to privatisation.

To test this conjecture, we can read the coefficients of the variable TIME when we control for the Government's ideology and credibility. As Table 8 shows, the signs and statistically significance of the variable TIME are confirmed.

Creditors' legal protection also has an opposite effect on the two issues that we analyse. The coefficient of the variable CREDITOR is stable, negative, and highly statistically significant in the Probit analysis, but positive when we estimate the positive values ABROAD. The dual role of creditors rights is particularly difficult to interpret. However, the first result is of considerable interest, mostly when confronted with the strong effects of shareholders rights in OECD countries.

In non-OECD countries, shareholders rights are quite irrelevant in the decision to cross-list. The coefficient of the variable ANTID - albeit negative - are never significant. These results are consistent with the argument set forth by Berglof and Von Thadden (1999) that creditors' protection is particularly important in emerging economies, where stock markets are small and banks play a major role in project financing. Our result indicates that this happens to such an extent, as the inability of attracting credit due to inadequate bankruptcy laws forces Governments to raise capital abroad..

Another major difference between OECD and non-OECD countries stems from the analysis of the role of financial markets development. Table 8 shows that the stock market liquidity indicators (FLOAT) is negatively associated with a lower probability of an international offer. Governments in countries with less liquid capital markets tend to cross-list privatised firms more frequently 28 . This strategy allows them to tap more developed markets and possibly to "import" some liquidity also on their domestic markets. This is exactly the opposite of what we observe in OECD countries, where domestic financial development facilitates the cross-listing of shares since the largest part of volume is traded at home and an efficient home market provides a useful benchmark for the pricing abroad (Karolyi, 1998).

The intuition for the result might be that if financial markets are less developed - as in the majority of non-OECD countries - the domestic stock market is most unlikely to be the dominant one as most of the trading will take place abroad: the liquidity of the

\footnotetext{
${ }^{28}$ A completely analogous result would be obtained using the turnover ratio.
} 
home stock exchange is probably quite irrelevant for the formation of prices. Therefore, the decisive factor in this respect is that countries with less liquid markets will need cross-listing more than others, and they will therefore display a greater propensity to engage in this type of operations.

Another important difference sticks out when evaluating the impact of foreign direct investment (FDI) in the two sub-samples. A lower level of foreign investments is associated with a larger percentage of stock placed abroad. Now the interpretation is straightforward: if capital inflows are scarce, Governments are force to finance companies abroad. This results is in stark contrast with the analysis in the OECD subsample, where FDI increased the likelihood of cross-listing.

Finally, foreign debt as a percentage of GDP (FDEBT) ${ }^{29}$ warrants attention: A high foreign debt-to-GNP ratio (FDEBT) decreases the likelihood of an international listing. A high level of foreign debt could be interpreted as a signal of high level of sovereign risk. If international investors are fearful of the issuer's financial distress, Governments are forced to privatise firms on domestic markets. A similar result emerges when public deficit is considered instead of foreign debt, but results are much weaker in terms of statistical significance $\frac{30}{3}$. It is particularly important to test the empirical validity of this interpretation of the coefficient by controlling for Government's credibility as a proxy for country risk. In Table 8 , one can see that the coefficients of the FDEBT variable are stable and significant also when CREDIB is included as regressor.

\section{Concluding remarks}

A useful way to conclude the paper is first of all to compare the main stories emerging from our analyses, to stress the role of the variables in the two phases of the decision process.

Macro variables. Variables indicating a country's financial solidity play an ambiguous role. In OECD countries, the conventional wisdom suggesting that Governments will try to sell abroad more - hoping to get higher revenues - when their public accounts are troubled is confirmed. On the contrary, in non-OECD countries while

\footnotetext{
${ }^{29}$ Due to missing data, we are allowed to introduce foreign debt as regressor only in the empirical analysis of non-OECD countries. To the best of our knowledge, data on foreign debt for several European countries are not available from any centralised source, and mixing sources proves to be very problematic. All the data we use come from World Bank World Debt Tables.

${ }^{30}$ However, the use of the deficit to GDP ratio renders the interpretation of coefficients difficult due to multicollinearity.
} 
public deficit is not a significant variable, the ratio of foreign debt to GNP takes on the role of signals of the credibility of macro policies, so that high values of this variable are associated to lesser use of foreign sales.

Institutional variables. Our interpretation of the behaviour of macroeconomic variables seems consistent with the fact that institutional credibility is relevant only in non-OECD countries, while the analysis is not even feasible in OECD countries, where the variable displays too little variability.

Investors' protection (the variable ANTID) negatively affects the openness of these privatisation deals. Governments try to induce investors to buy shares of privatised companies by importing investors' protection from abroad. A somehow similar interpretation can be given to the behaviour of the index of creditors' protection: given that creditors are very protected by domestic laws, foreign investors are less keen of investing in the company, and foreign exposure is limited. While shareholders' protection matters more in advanced economies, creditors' protection matters more in non-OECD

Financial variables. Stock market variables also play very distinct roles of in the two groups of countries. In OECD countries, the home market is likely to be the dominant one in terms of trade volume, and its liquidity encourages foreign sales. The opposite happens in non-OECD countries, where the home market's lack of liquidity is irrelevant to investors (most of the trading will take place abroad anyway) but it induces the Government to resort more aggressively to this strategy.

Sector dummies. Companies operating in telecommunications are always natural candidates for listing abroad. Other sectors seems to matter only in OECD countries, while in non-OECD countries the treatment of firms appears to be more homogeneous

Political economy. This analysis provides support to the theoretical results on the political economy of privatisations: Governments declaring support to market oriented policies sell fewer shares of privatised companies into foreign markets. However, in nonOECD countries we have an additional element, that might deserve further theoretical analysis: market oriented Governments seem to use foreign markets to improve their commitment to a market oriented policy, and are thus more likely to use them in the privatisation process. 


\section{References}

Alesina, A., N. Roubini (1992), Political cycles in OECD economies, Review of Economics Studies, 59, 663-88.

Amemiya, T. (1985), Advanced Econometrics, Oxford: Basil Blackwell.

Amihud, Y., and H. Mendelson (1991), Liquidity, asset prices and financial policy, Financial Analysts Journal, 47, 56-66.

Anderson, R. and P. Tychon (1993), Competition among European financial markets: the case of cross-listed Belgian equities, Revue de la Banque.

Asher, B. (1996), The development of a global security market, in Oditah F., (ed.) The Future for the global securities market. Oxford: Clarendon Press.

Baker, H. K. (1996), Trading location and liquidity: An analysis of U.S. dealer and agency markets for common stocks, Financial Markets, Institutions \& Instruments, 5(4).

Berglof, E. and E.-L. von Thadden (1999), The changing corporate governance paradigm: implications for transition and developing countries, mimeo.

Biais, B. and E. Perotti (1997), Machiavellian privatization, University of Amsterdam and University of Toulouse, mimeo, forthcoming in American Economic Review.

Bortolotti, B., M. Fantini and D. Siniscalco (1999), Privatisation: politics, institutions and financial markets, mimeo, Feem, Milan.

Demirgüç-Kunt, A. and R. Levine (1996), Stock market development and financial intermediaries: Stylized facts, World Bank Economic Review, 10, 291-321.

Demirgüç-Kunt, A. and V. Maksimovic (1996), Stock market development and the financial choices of firms, World Bank Economic Review, 10, 341-369.

Domowitz, I., J. Glen and A. Madhavan (1988) International cross-listing and order flow migration: evidence from an emerging market, Journal of Finance, 53, 2001-27.

Fuerst, O. (1997), The post-listing operating performance of firms with global listing of stocks, Working paper, International Center for Finance at Yale, Yale School of Management, mimeo.

Fuerst, O. (1998), A theoretical analysis of the investor protection regulations argument for global listing of stocks, International Center for Finance at Yale, Yale School of Management, mimeo.

Fulghieri, P. (1999), Choosing an exchange to list equity: a theory of dual listing requirements, and competition among exchanges mimeo, INSEAD.

Holmström, B. and J. Tirole (1993), Market liquidity and performance monitoring, Journal of Political Economy, 101, 678-709.

Huddart, S., J. Hughers and M. Burnnermeier (1998), Disclosure requirements and stock exchange listing choice in an international context, Journal of Accounting and Economics, 26, pp.

Jones, S., W. Megginson, R. Nash and J. Netter (1999), Share issue privatizations as financial means to political and economic ends, Journal of Financial Economics, forthcoming. 
Karolyi, A. (1998), Why do companies list abroad? A survey of the evidence and its managerial implications, Financial markets, Institutions and Instruments, 7, New York University, Salomon Centre.

La Porta, R., F. López-de-Silanes, A. Shleifer and R. Vishny (1998), Law and finance, Journal of Political Economy, 106, 1113-55.

Leuz, C. and R.E. Verrecchia (1999) The economic consequences of increased disclosure, mimeo.

Lewis, K. (1999) Trying to Explain Home Bias in Equities and Consumption, Journal of Economic Literature, 37(2), 571-608.

Licht, A. N. (1998), Regulatory arbitrage for real: international securities regulation in a world of interacting securities markets, Virginia Journal of International Law, 38, 563-638.

Lipsey, R. (1999), The role of foreign direct investment in international capital flows, NBER Working Paper No. 8094.

López-de-Silanes, F. (1997), Determinants of privatization prices, Quarterly Journal of Economics 112, 965- 1025.

Lombardo, D., M. Pagano (1999), Legal determinants of the return of equity, Università di Salerno, mimeo.

Megginson W. and Netter, J. (1999), From state to market: a survey of empirical studies of privatization, FEEM Note di Lavoro n. 1.

Modigliani F. and E. Perotti (1999), Security versus bank finance: the importance of a proper enforcement of legal rules, FEEM Note di Lavoro n. 37.

Pagano, M. (1989), Trading volume and asset liquidity, Quarterly Journal of Economics, $104,255-74$.

Pagano, M. (1993), The flotation of companies on the stock market: a coordination failure model, European Economic Review, 37, 1101-1125.

Pagano, M., F. Panetta and L. Zingales (1998), Why do companies go public? An empirical analysis, Journal of Finance, 53, 1-42.

Pagano, M., A. Roell and J. Zechner (1999), The Geography of Equity Listing: Why Do European Companies List Abroad?, mimeo.

Pagano, M. and B. Steil (1996), Equity trading I: the evolution of European trading systems, in B. Steil (ed.) The European equity markets, The Royal Institute for International Affairs, London.

Perotti, E. (1995), Credible privatisation, American Economic Review 85, 847-59.

Perotti, E., and P. Van Oijen (1999), Privatization, political risk, and stock market development in emerging economies, FEEM Note di Lavoro n. 38.

Rajan, R. and L. Zingales (1998) Financial dependence and growth, American Economic Review, 88, 559-87. 


\section{Table 1. Description of the variables}

\begin{tabular}{|c|c|c|}
\hline Variable & Definition & Source \\
\hline ABROAD & $\begin{array}{l}\text { Percentage of privatised stock placed on non- } \\
\text { domestic financial markets (flag Rule } 144 \mathrm{a} \text { included. The } \\
\text { variable refers to each single PO. }\end{array}$ & Privatisation International \\
\hline GDP & $\begin{array}{l}\text { Country average of the GDP/population ratio for the } \\
\text { privatisation period (starting from the first PO and the last } \\
\text { PO reported). Gross domestic product is expressed in } \\
\text { constant US dollars } 1987 \text {. Population is current mid-year } \\
\text { population. The variable is constant across POs in a given } \\
\text { country. }\end{array}$ & $\begin{array}{l}\text { World Bank Indicators, } \\
\text { World Development } \\
\text { Indicators }\end{array}$ \\
\hline GROWTH & $\begin{array}{l}\text { Country average growth rates of GDP at constant } \\
\text { prices } 1987 \text { for the privatisation period (starting from the } \\
\text { first PO and the last PO reported). The variable is constant } \\
\text { across POs in a given country. }\end{array}$ & $\begin{array}{l}\text { World Bank Indicators, } \\
\text { World Development } \\
\text { Indicators }\end{array}$ \\
\hline SAVE & $\begin{array}{l}\text { Country average of the gross domestic savings/GDP } \\
\text { ratio at for the privatisation period (starting from the first PO } \\
\text { and the last PO reported). Gross domestic savings is } \\
\text { domestic product minus total consumption. The variable is } \\
\text { constant across POs in a given country. }\end{array}$ & $\begin{array}{l}\text { World Bank Indicators, } \\
\text { World Development } \\
\text { Indicators }\end{array}$ \\
\hline UNEMP & $\begin{array}{l}\text { Country average of the unemployment rate in the } \\
\text { privatisation period (starting from the first PO and the last } \\
\text { PO reported). The variable is constant across POs in a given } \\
\text { country. }\end{array}$ & $\begin{array}{lr}\text { United Nations } & \text { Statistics } \\
\text { Yearbook, World Bank } & \text { Indicators, } \\
\text { IMF International } & \text { Financial } \\
\text { Statistics, OECD } & \text { Economic } \\
\text { Outlook } & \end{array}$ \\
\hline FDI & $\begin{array}{l}\text { Country average of the FDI/GNP ratio in the three } \\
\text { years before each privatisation. FDI is measured as the } \\
\text { balance of the series "foreign direct investment in country" } \\
\text { and "direct investment abroad". }\end{array}$ & $\begin{array}{l}\text { World Bank Indicators, } \\
\text { IMF International Financial } \\
\text { Statistics, Datastream }\end{array}$ \\
\hline TRADE & $\begin{array}{l}\text { Country average of the (Export + Import)/GNP ratio } \\
\text { in the three years before each privatisation. All series are in } \\
\text { current value. }\end{array}$ & $\begin{array}{l}\text { World Bank Indicators, } \\
\text { World Development } \\
\text { Indicators, } \\
\text { IMF International Financial } \\
\text { Statistics, Datastream }\end{array}$ \\
\hline FDEBT & $\begin{array}{l}\text { Country average of the Foreign Debt/GNP ratio in } \\
\text { the three years before each privatisation. Foreign Debt is } \\
\text { "public and publicly guaranteed debt". }\end{array}$ & $\begin{array}{l}\text { World Debt Tables, } \\
\text { World Development } \\
\text { Indicators, } \\
\text { IMF International Financial }\end{array}$ \\
\hline
\end{tabular}




\begin{tabular}{|c|c|c|}
\hline & & Statistics, Datastream \\
\hline DEFICIT & $\begin{array}{l}\text { Country average of the Deficit as a percentage of } \\
\text { GDP in the three years before each privatisation. }\end{array}$ & $\begin{array}{lr}\text { World } & \text { Development } \\
\text { Indicators } & \\
\quad \text { International } & \text { Financial } \\
\text { Statistics } & \end{array}$ \\
\hline ENERGY & $\begin{array}{l}\text { Dummy taking the value one when the privatised } \\
\text { company belongs to the following sectors: electricity } \\
\text { (generation), oil and gas production. }\end{array}$ & Privatisation International \\
\hline FINANCE & $\begin{array}{l}\text { Dummy taking the value one when the privatised } \\
\text { company belongs to the following sectors: banking, } \\
\text { financial intermediation, insurance. }\end{array}$ & Privatisation International \\
\hline INDUSTRY & $\begin{array}{l}\text { Dummy taking the value one when the privatised } \\
\text { company belongs to the following sectors: aerospace, } \\
\text { chemicals, construction, electrical, machinery, metals, } \\
\text { mining, motor vehicles, paper, pharmaceutical, rail } \\
\text { equipment, tobacco. }\end{array}$ & Privatisation International \\
\hline TLC & $\begin{array}{l}\text { Dummy taking the value one when the privatised } \\
\text { company belongs to the telecommunication sector. }\end{array}$ & Privatisation International \\
\hline UTILITY & $\begin{array}{l}\text { Dummy taking the value one when the privatised } \\
\text { company belongs to the following sectors: airline, airport, } \\
\text { electricity distribution, gas distribution, rail services, rail- } \\
\text { track, water and sewerage. }\end{array}$ & Privatisation International \\
\hline OTHER & $\begin{array}{l}\text { Dummy taking the value one when the privatised } \\
\text { company belongs to the following sectors: holding } \\
\text { company, multiple. }\end{array}$ & Privatisation International \\
\hline IPO & $\begin{array}{l}\text { Dummy taking the value when the PO considered is } \\
\text { an IPO. }\end{array}$ & Privatisation International \\
\hline TIME & $\begin{array}{l}\text { Number of months elapsed from a country's first } \\
\text { privatisation and the date of PO which is considered. }\end{array}$ & Privatisation International \\
\hline CAP & $\begin{array}{l}\text { Market capitalisation/GDP ratio in the year before } \\
\text { each privatisation. Market capitalisation refers to a country's } \\
\text { main stock exchange. }\end{array}$ & 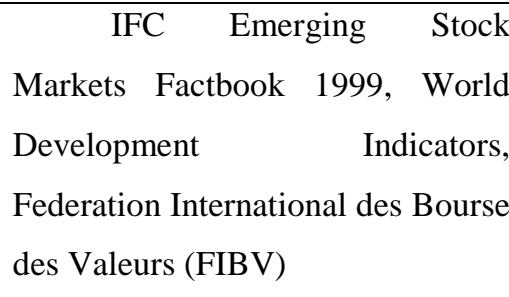 \\
\hline FLOAT & $\begin{array}{l}\text { Trading value/GDP ratio in the year before each } \\
\text { privatisation. Trading value refers to a country's main stock } \\
\text { exchange. }\end{array}$ & $\begin{array}{l}\text { IFC Emerging } \\
\text { Markets Factbook } \\
\text { Development } \\
\text { Federation International des Bourse } \\
\text { Forld } \\
\text { des Valeurs (FIBV) }\end{array}$ \\
\hline TURNOVER & Trading value/market capitalisation ratio in the year & IFC $\quad$ Emerging \\
\hline
\end{tabular}




\begin{tabular}{|c|c|c|}
\hline & $\begin{array}{l}\text { before each privatisation. Trading value and market } \\
\text { capitalisation refer to a country's main stock exchange. }\end{array}$ & $\begin{array}{l}\text { Markets Factbook 1999, Federation } \\
\text { International des Bourse des } \\
\text { Valeurs (FIBV) }\end{array}$ \\
\hline ANTID & $\begin{array}{l}\text { The index measures the legal protection that a } \\
\text { country's company law provides against the risk of } \\
\text { expropriation by managers. The variable takes into account } \\
\text { the existence by law of (i) proxy voting by mail, (ii) } \\
\text { cumulative voting for directors, (iii) oppressed minority } \\
\text { mechanisms, (iv) requirements about the deposit of shares } \\
\text { prior to general share holders meeting, (v) minimum } \\
\text { percentage of shares to call for an extraordinary meeting at } \\
10 \% \text { or below, and (vi) the pre-emptive rights that can be } \\
\text { waived only by a shareholder's vote. It ranges from } 0 \text { to } 6 \text {. }\end{array}$ & La Porta et al. (1998) \\
\hline CREDITOR & $\begin{array}{l}\text { This index measures the legal protection that a } \\
\text { country's company law affords to creditors. The variable } \\
\text { takes into account the existence by law of (i) creditors } \\
\text { consent to file for reorganisation, (ii) automatic stay on } \\
\text { assets, (iii) special rights for secured creditors, and (iv) } \\
\text { management stay on the reorganisation process. It ranges } \\
\text { from } 0 \text { to } 4 \text {. }\end{array}$ & La Porta et al. (1998) \\
\hline CREDIB & $\begin{array}{l}\text { Average grades obtained by the country in terms of } \\
\text { risk of contract repudiation and risk of expropriation in the } \\
\text { year before each privatisation. }\end{array}$ & $\begin{array}{l}\text { International Country Risk } \\
\text { Guide }\end{array}$ \\
\hline ENFORCE & $\begin{array}{l}\text { Average grades obtained by the country in terms of } \\
\text { corruption, law and order, and bureaucratic quality in the } \\
\text { year before each privatisation. It ranges from } 0 \text { to } 6 \text {. }\end{array}$ & $\begin{array}{l}\text { International Country Risk } \\
\text { Guide }\end{array}$ \\
\hline RIGHT & $\begin{array}{l}\text { Dummy taking the value } 1 \text { when the privatisation } \\
\text { was implemented by a government supported by a } \\
\text { "democratic conservative party". Democratic conservative } \\
\text { parties are defined as parties adhering to traditional values in } \\
\text { combination with free-market ideology and law-and-order } \\
\text { positions. }\end{array}$ & $\begin{array}{l}\text { Wilfried Derksen's } \\
\text { Electoral Web Sites, Banks et al. } \\
\text { (1998) Political Handbook of the } \\
\text { World. }\end{array}$ \\
\hline LEFT & $\begin{array}{l}\text { Dummy taking the value } 1 \text { when the privatisation } \\
\text { was implemented by a government supported by "left wing } \\
\text { parties". Left-wing parties include labour, socialist, social- } \\
\text { democratic, and communist parties. }\end{array}$ & $\begin{array}{l}\text { Wilfried Derksen's } \\
\text { Electoral Web Sites, Banks et al. } \\
\text { (1998) Political Handbook of the } \\
\text { World. }\end{array}$ \\
\hline CENTER & $\begin{array}{l}\text { Dummy taking the value } 1 \text { when the privatisation } \\
\text { was implemented by a government supported by "centrist" } \\
\text { parties. This label include parties which are in the centre of } \\
\text { the political spectrum without officially adhering to free }\end{array}$ & $\begin{array}{l}\text { Wilfried Derksen's } \\
\text { Electoral Web Sites, Banks et al. } \\
\text { (1998) Political Handbook of the } \\
\text { World. }\end{array}$ \\
\hline
\end{tabular}




\begin{tabular}{|c|c|c|}
\hline & $\begin{array}{l}\text { market values, Christian-democratic parties and wide } \\
\text { coalitional Governments without a clearly discernible } \\
\text { orientation. }\end{array}$ & \\
\hline NONDEM & $\begin{array}{l}\text { Dummy taking the value } 1 \text { when the privatisation } \\
\text { was implemented by a dictatorial, military, or authoritarian } \\
\text { ruler. }\end{array}$ & $\begin{array}{l}\text { Wilfried Derksen's } \\
\text { Electoral Web Sites, Banks et al. } \\
\text { (1998) Political Handbook of the } \\
\text { World. }\end{array}$ \\
\hline
\end{tabular}


Table 2: Descriptive statistics by country

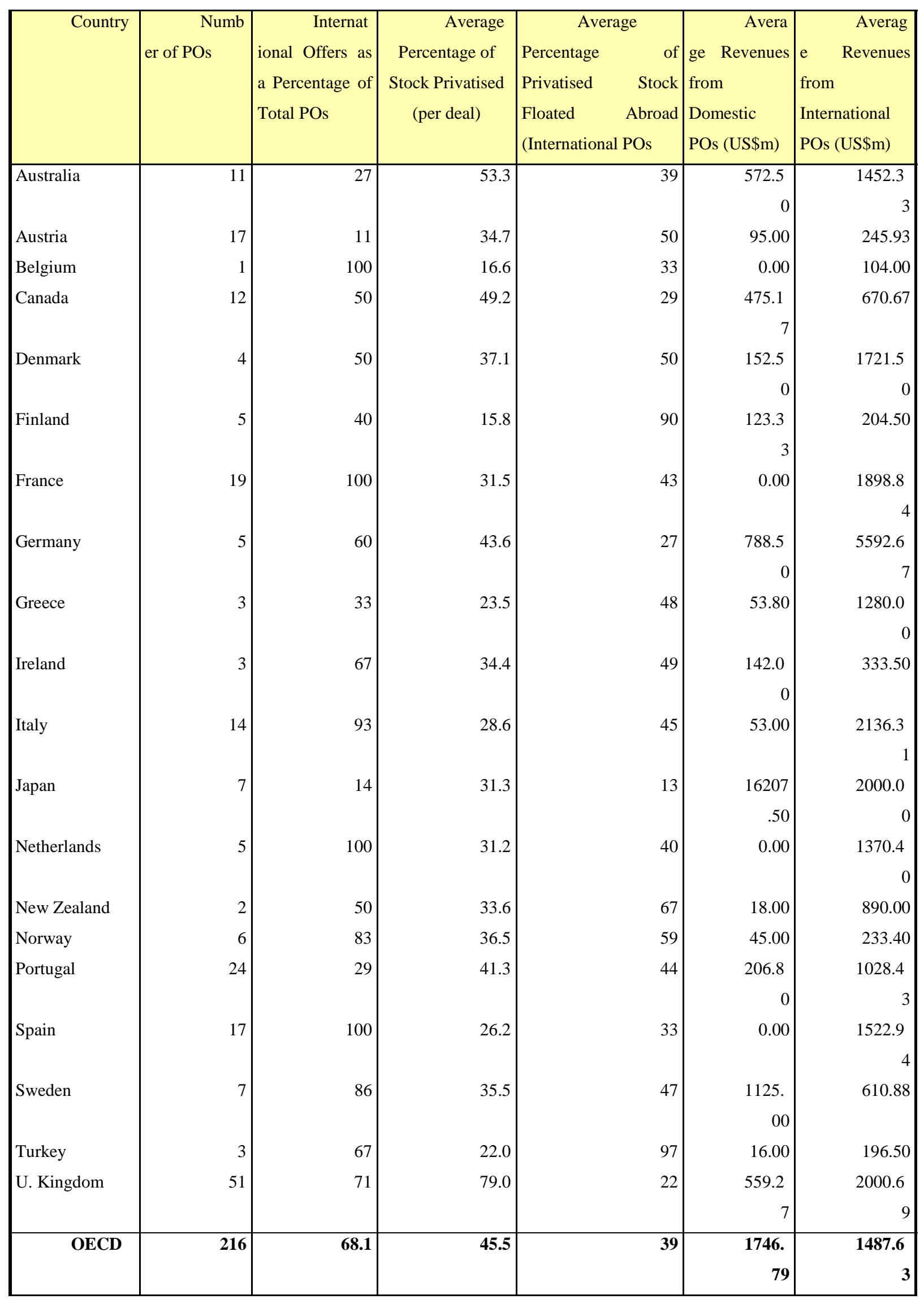




\begin{tabular}{|c|c|c|c|c|c|c|}
\hline Argentina & 6 & $67 \mid$ & 30.4 & 44 & 1038. & 952.25 \\
\hline Brazil & 5 & 60 & 23.7 & 76 & 806.4 & 343.10 \\
\hline Colombia & 1 & 0 & 99.2 & 0 & 500.0 & 0.00 \\
\hline Egypt & 43 & 7 & 32.6 & 100 & 31.47 & 109.33 \\
\hline India & 11 & 18 & 24.6 & 100 & 342.1 & 403.35 \\
\hline Indonesia & 4 & 100 & 23.3 & 73 & 0.00 & 871.25 \\
\hline Israel & 19 & 11 & 22.8 & 17 & 124.9 & 174.20 \\
\hline Kenya & 5 & 20 & 23.4 & 27 & 10.15 & 46.00 \\
\hline Korea & 4 & 0 & 16.1 & 0 & 616.2 & 0.00 \\
\hline Malaysia & 8 & 25 & 26.1 & 54 & 388.1 & 687.50 \\
\hline Nigeria & 19 & 0 & 42.7 & 0 & 1.68 & 0.00 \\
\hline Pakistan & 2 & 50 & 30.8 & 83 & 82.00 & 997.00 \\
\hline Peru & 3 & 100 & 33.9 & 48 & 0.00 & 495.67 \\
\hline Philippines & 2 & 50 & 10.2 & 28 & 80.00 & 71.00 \\
\hline Singapore & 8 & 0 & 29.1 & 0 & 537.7 & 0.00 \\
\hline South Africa & 2 & 0 & 83.0 & 0 & 650.5 & 0.00 \\
\hline Sri Lanka & 3 & 33 & 36.6 & 95 & 1.00 & 75.00 \\
\hline Taiwan & 18 & 5 & 19.2 & 35 & 316.6 & 885.00 \\
\hline Thailand & 8 & 87 & 27.8 & 24 & 85.00 & 117.83 \\
\hline Mexico & 2 & 100 & 9.4 & 91 & 0.00 & 178.00 \\
\hline Venezuela & 1 & 100 & 31.2 & 77 & 0.00 & 1026.0 \\
\hline Zimbabwe & 2 & 0 & 47.5 & 0 & 30.75 & 0.00 \\
\hline NON OECD & 176 & 22 & 29.6 & 57 & $\begin{array}{r}194.3 \\
1\end{array}$ & 530.61 \\
\hline \begin{tabular}{|l|} 
WHOLE \\
SAMPLE
\end{tabular} & 392 & 47.2 & 38.7 & 42 & $\begin{array}{r}711.8 \\
0\end{array}$ & $\begin{array}{r}1291.0 \\
6\end{array}$ \\
\hline
\end{tabular}

Table 3: Descriptive statistics by sector 


\begin{tabular}{|c|c|c|c|c|c|c|}
\hline & $\mathrm{Nu}$ & Internat & Average & Average & Avera & Average \\
\hline & $\begin{array}{ll}\text { mber } & \text { of } \\
\text { POs }\end{array}$ & $\begin{array}{l}\text { ional Offers as } \\
\text { a Percentage of } \\
\text { Total POs }\end{array}$ & $\begin{array}{r}\text { Percentage of } \\
\text { Stock Privatised } \\
\text { (per deal) }\end{array}$ & \begin{tabular}{|lr} 
Percentage & of \\
Privatised & Stock \\
Floated & Abroad \\
(International & Pos)
\end{tabular} & $\begin{array}{l}\text { ge Firm Size } \\
\text { (Domestic } \\
\text { POs) (US\$m) }\end{array}$ & $\begin{array}{l}\text { Firm Size } \\
\text { (International } \\
\text { POs) (US\$m) }\end{array}$ \\
\hline \multicolumn{7}{|l|}{ Whole } \\
\hline TLC & 44 & 63.64 & 23 & 60 & $\begin{array}{r}6105 \\
0.62\end{array}$ & $\begin{array}{r}14160 . \\
28\end{array}$ \\
\hline ENERGY & 33 & 60.61 & 26 & 37 & $\begin{array}{r}4126 . \\
23\end{array}$ & $\begin{array}{r}12571 . \\
50\end{array}$ \\
\hline FIN & 90 & 40.00 & 35 & 46 & $\begin{array}{r}974.3 \\
4\end{array}$ & $\begin{array}{r}3199.0 \\
9\end{array}$ \\
\hline IND & $\begin{array}{c}13 \\
6\end{array}$ & 31.62 & 36 & 49 & $\begin{array}{r}936.7 \\
8\end{array}$ & $\begin{array}{r}2134.2 \\
2\end{array}$ \\
\hline UTILITY & 54 & 59.26 & 58 & 30 & $\begin{array}{r}1206 . \\
73\end{array}$ & $\begin{array}{r}2267.4 \\
5\end{array}$ \\
\hline OTHERS & 35 & 74.28 & 65 & 26 & $\begin{array}{r}2919 . \\
18\end{array}$ & $\begin{array}{r}3015.2 \\
8\end{array}$ \\
\hline TOTAL & $\begin{array}{r}39 \\
2\end{array}$ & 47.19 & 39 & 42 & $\begin{array}{r}6093 . \\
98\end{array}$ & $\begin{array}{r}5462.7 \\
8\end{array}$ \\
\hline \multicolumn{7}{|l|}{ OECD } \\
\hline TLC & 24 & 70.83 & 27 & 45 & \begin{tabular}{|c|}
1338 \\
58.04
\end{tabular} & $\begin{array}{r}15769 . \\
52\end{array}$ \\
\hline ENERGY & 23 & 73.91 & 24 & 38 & $\begin{array}{r}8196 . \\
53\end{array}$ & $\begin{array}{r}14783 . \\
28\end{array}$ \\
\hline FIN & 52 & 57.69 & 38 & 47 & $\begin{array}{r}1102 . \\
62\end{array}$ & $\begin{array}{r}3626.7 \\
5\end{array}$ \\
\hline IND & 56 & 64.28 & 44 & 45 & $\begin{array}{r}1441 . \\
68\end{array}$ & $\begin{array}{r}2237.3 \\
3\end{array}$ \\
\hline UTILITY & 38 & 71.05 & 65 & 30 & $\begin{array}{r}2109 . \\
49\end{array}$ & $\begin{array}{r}2445.9 \\
2\end{array}$ \\
\hline OTHERS & 23 & 86.96 & 80 & 22 & $\begin{array}{r}645.0 \\
9\end{array}$ & $\begin{array}{r}3381.4 \\
9\end{array}$ \\
\hline TOTAL & $\begin{array}{r}21 \\
6 \\
\end{array}$ & 68.06 & 46 & 39 & $\begin{array}{r}1542 \\
6.33\end{array}$ & $\begin{array}{r}5839.5 \\
6\end{array}$ \\
\hline \multicolumn{7}{|l|}{ Non-OECD } \\
\hline TLC & 20 & 55.00 & 18 & 85 & $\begin{array}{r}4422 . \\
63\end{array}$ & $\begin{array}{r}10941 . \\
79\end{array}$ \\
\hline ENERGY & 10 & 30.00 & 31 & 31 & 637.4 & 3724.3 \\
\hline
\end{tabular}




\begin{tabular}{|l|r|r|r|r|r|r|}
\hline FIN & 38 & 15.79 & 30 & & 0 & 7 \\
IND & 80 & 8.75 & 30 & 883.3 & 638.12 \\
UTILITY & 16 & 31.25 & 40 & 69 & 790.4 & 1618.6 \\
& & & & & & \\
OTHERS & 12 & 50.00 & 24 & 34 & 303.9 & 1339.4 \\
& & & & 38 & 6330. & 1855.6 \\
\hline TOTAL & $\mathbf{1 7}$ & $\mathbf{2 2 . 0 1}$ & $\mathbf{3 0}$ & & 32 & 1 \\
& $\mathbf{6}$ & & & $\mathbf{5 7}$ & $\mathbf{1 1 0 2 .}$ & $\mathbf{3 9 6 6 . 1}$ \\
& & & & & $\mathbf{2 6}$ & $\mathbf{1}$ \\
\hline
\end{tabular}


Table 4: Descriptive statistics by political dummies

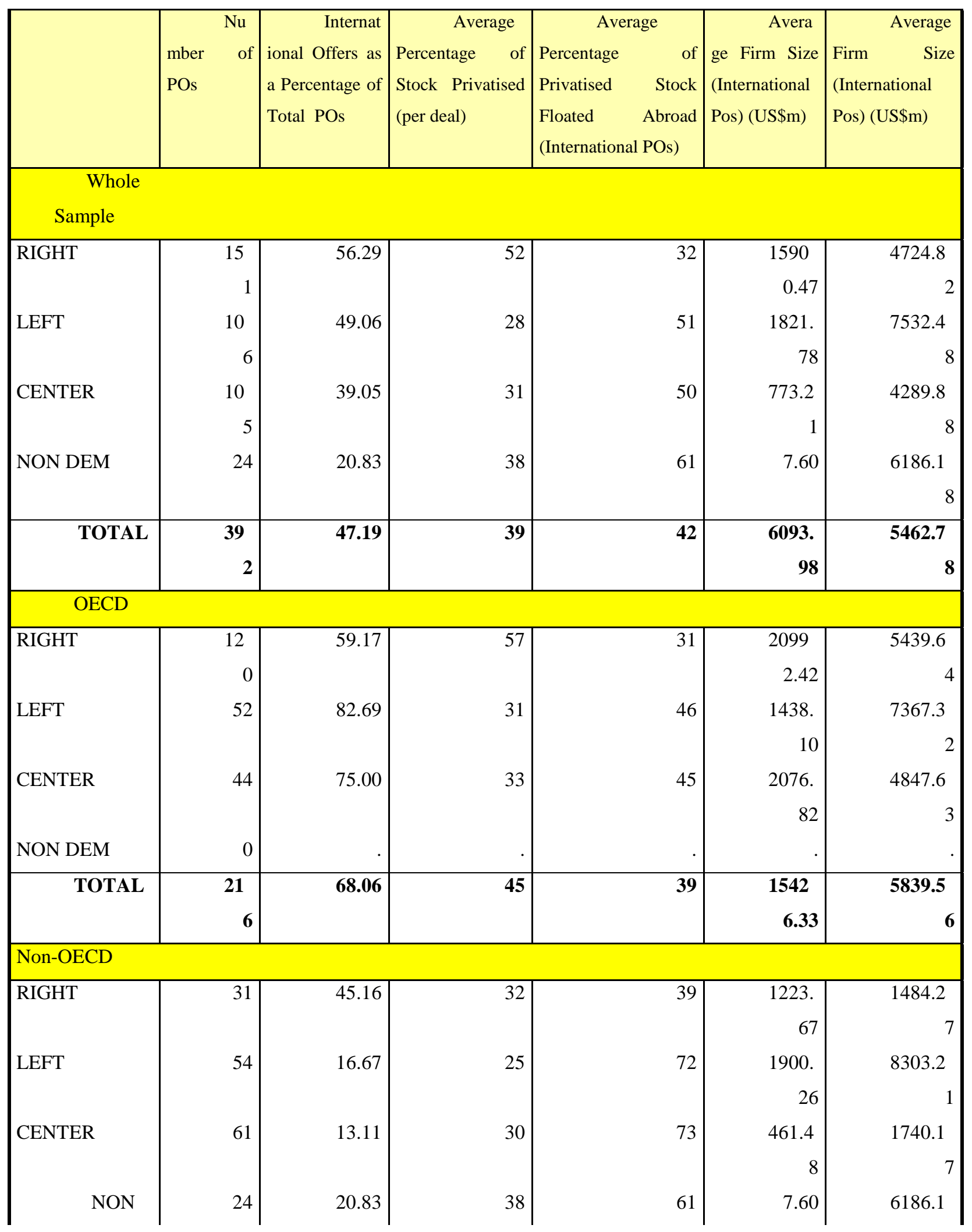




\begin{tabular}{|r|r|r|r|r|r|r|}
\hline DEM & & & & & & 8 \\
\hline TOTAL & 17 & 22.01 & 30 & 57 & 1102. & 3966.1 \\
& 6 & & & & 26 & 1 \\
\hline
\end{tabular}


Table 5: Mean values of statistical variables and test of means

\begin{tabular}{|c|c|c|c|c|c|c|c|c|c|}
\hline & \multicolumn{3}{|c|}{ Whole sample } & \multicolumn{3}{|c|}{ OECD } & \multicolumn{3}{|c|}{ Non-OECD } \\
\hline & \begin{tabular}{|l} 
ad $>0$ \\
\end{tabular} & oad $=0$ & 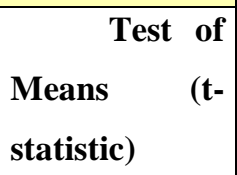 & $\begin{array}{r}\text { Ab } \\
\text { road }>0\end{array}$ & oad=0 & \begin{tabular}{|lr|}
\multicolumn{1}{|r}{ Test } & of \\
Means & $(\mathrm{t}-$ \\
statistic $)$ &
\end{tabular} & $\begin{array}{l}\text { Abr } \\
\text { oad }>0\end{array}$ & oad=0 & 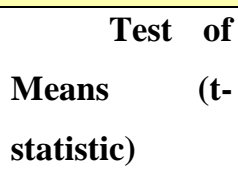 \\
\hline REVENUES & $\begin{array}{r}1126 . \\
71\end{array}$ & $\begin{array}{r}713 \\
.08\end{array}$ & 1.52 & $\begin{array}{l}138 \\
2.21\end{array}$ & $\begin{array}{r}1765 \\
.88\end{array}$ & -0.52 & $\begin{array}{r}356 . \\
45\end{array}$ & $\begin{array}{r}194 . \\
31\end{array}$ & $\begin{array}{r}* * * \\
2.13\end{array}$ \\
\hline FIRMSIZE & $\begin{array}{r}5081 . \\
17\end{array}$ & $\begin{array}{l}611 \\
4.76\end{array}$ & -0.36 & $\begin{array}{l}572 \\
7.07\end{array}$ & $\begin{array}{r}1562 \\
3.76\end{array}$ & -1.22 & $\begin{array}{l}328 \\
2.58\end{array}$ & $\begin{array}{r}1102 \\
.27\end{array}$ & $\begin{array}{l}* * * \\
2.51\end{array}$ \\
\hline PILPRO & $\begin{array}{r}11072 \\
.42\end{array}$ & $\begin{array}{l}725 \\
5.68\end{array}$ & $\begin{array}{l}* * * \\
5.59\end{array}$ & $\begin{array}{r}137 \\
57.01\end{array}$ & $\begin{array}{r}1277 \\
6.28\end{array}$ & 0.85 & $\begin{array}{l}309 \\
6.45\end{array}$ & $\begin{array}{r}4535 \\
.39\end{array}$ & $\begin{array}{r}* * \\
-2.13\end{array}$ \\
\hline GROWTH & 0.24 & $\begin{array}{r}1.1 \\
1\end{array}$ & $\begin{array}{r}* * * \\
-5.19\end{array}$ & $\begin{array}{r}0.0 \\
7\end{array}$ & 0.27 & $\begin{array}{r}* \\
-1.90\end{array}$ & 0.75 & 1.52 & $\begin{array}{r}* * \\
-2.47\end{array}$ \\
\hline SAVE & 1.23 & $\begin{array}{r}3.0 \\
6\end{array}$ & $\begin{array}{r}* * * \\
-2.99\end{array}$ & $\begin{array}{r}0.8 \\
3\end{array}$ & 3.00 & $\begin{array}{r}* \\
-1.90\end{array}$ & 2.48 & 3.10 & -0.65 \\
\hline TRADE & 0.56 & $\begin{array}{r}0.7 \\
2\end{array}$ & $\begin{array}{r}* * * \\
-3.29\end{array}$ & $\begin{array}{r}0.5 \\
4\end{array}$ & 0.55 & -0.38 & 0.61 & 0.80 & $\begin{array}{r}* \\
-1.93\end{array}$ \\
\hline FDI & 0.01 & $\begin{array}{r}0.0 \\
1\end{array}$ & -1.49 & $\begin{array}{r}0.0 \\
0\end{array}$ & 0.01 & -0.54 & 0.03 & 0.02 & 0.52 \\
\hline FDEBT & 0.21 & $\begin{array}{r}0.6 \\
8\end{array}$ & $\begin{array}{r}* * * \\
-7.10\end{array}$ & $\begin{array}{r}0.1 \\
0\end{array}$ & 0.10 & 0.01 & 0.47 & 0.88 & $\begin{array}{r}* * * \\
-6.48\end{array}$ \\
\hline DEFICIT & 3.91 & $\begin{array}{r}3.0 \\
4\end{array}$ & $\begin{array}{r}* * \\
2.37\end{array}$ & $\begin{array}{r}4.6 \\
8\end{array}$ & 4.01 & 1.54 & 1.45 & 2.56 & $\begin{array}{r}* \\
-1.84\end{array}$ \\
\hline
\end{tabular}




\begin{tabular}{|c|c|c|c|c|c|c|c|c|c|}
\hline CAP & 39.35 & $\begin{array}{r}33 . \\
65\end{array}$ & $\begin{array}{r}* \\
1.89\end{array}$ & $\begin{array}{r}43 . \\
71\end{array}$ & $\begin{array}{r}39.4 \\
8\end{array}$ & 1.06 & $\begin{array}{r}26.2 \\
7\end{array}$ & $\begin{array}{r}30.7 \\
5\end{array}$ & -1.08 \\
\hline FLOAT & 40.26 & $\begin{array}{r}43 . \\
95\end{array}$ & -0.57 & $\begin{array}{c}45 . \\
33\end{array}$ & $\begin{array}{r}28.4 \\
5\end{array}$ & $\begin{array}{r}* * * \\
4.75\end{array}$ & $\begin{array}{r}25.0 \\
6\end{array}$ & $\begin{array}{r}51.6 \\
5\end{array}$ & $\begin{array}{r}* * \\
-2.19\end{array}$ \\
\hline TURNOVER & 1.43 & & 0.29 & $\begin{array}{r}1.7 \\
1\end{array}$ & 1.14 & $\begin{array}{r}* \\
1.95\end{array}$ & 0.58 & 1.48 & $\begin{array}{r}* * * \\
-3.71\end{array}$ \\
\hline ANTID & 3.19 & & -0.07 & $\begin{array}{r}3.3 \\
1\end{array}$ & 3.66 & $\begin{array}{r}* * \\
-2.08\end{array}$ & 2.83 & 2.96 & -1.00 \\
\hline CREDITOR & 2.12 & & $\begin{array}{r}* * * * \\
-7.52\end{array}$ & $\begin{array}{r}2.0 \\
3\end{array}$ & 2.01 & 0.08 & 2.52 & 3.54 & $\begin{array}{r}* * * \\
-4.92\end{array}$ \\
\hline CREDIB & 9.14 & $\begin{array}{l}8.1 \\
\quad 1\end{array}$ & $\begin{array}{r}* * * \\
6.23\end{array}$ & $\begin{array}{r}9.5 \\
8\end{array}$ & 9.42 & $\begin{array}{r}* * * \\
2.59\end{array}$ & 7.84 & 7.47 & 1.24 \\
\hline
\end{tabular}

* Statistically significant at the $10 \%$ level;

** Statistically significant at the 5\% level;

*** Statistically significant at the $1 \%$ level. 
Table 6: The decision to sell abroad and stake sold on international markets: Sample selection estimation (whole sample)

\begin{tabular}{|c|c|c|c|c|c|c|}
\hline & $\begin{array}{l}\text { PROBIT } \\
\text { EQUATION }\end{array}$ & $\begin{array}{l}\text { REGRESSION } \\
\text { EQUATION }\end{array}$ & $\begin{array}{l}\text { PROBIT } \\
\text { EQUATION }\end{array}$ & $\begin{array}{l}\text { REGRESSION } \\
\text { EQUATION }\end{array}$ & $\begin{array}{l}\text { PROBIT } \\
\text { EQUATION }\end{array}$ & $\begin{array}{l}\text { REGRESSION } \\
\text { EQUATION }\end{array}$ \\
\hline CONSTANT & $\begin{array}{c}0.32 \\
(1.22)\end{array}$ & $\begin{array}{c}0.53^{* * * *} \\
(6.79)\end{array}$ & $\begin{array}{l}-0.20 \\
(-0.62)\end{array}$ & $\begin{array}{c}0.52^{* * * *} \\
(6.25)\end{array}$ & $\begin{array}{l}0.71 * * \\
(1.94)\end{array}$ & $\begin{array}{c}0.64^{* * * *} \\
(7.39)\end{array}$ \\
\hline PILPRO & $\begin{array}{c}0.75 \mathrm{E}-04 * * * \\
(6.25)\end{array}$ & & $\begin{array}{l}0.74 \mathrm{E}-04 * * * \\
\quad(6.26)\end{array}$ & & $\begin{array}{c}0.70 \mathrm{E}-04 * * * \\
(5.99)\end{array}$ & \\
\hline GROWTH & & $\begin{array}{c}-0.06 * * \\
(-2.71)\end{array}$ & & $\begin{array}{l}-0.06^{* *} \\
(-2.31)\end{array}$ & & $\begin{array}{c}-0.07 * * * \\
(-2.74)\end{array}$ \\
\hline SAVE & $\begin{array}{c}-0.11^{* * * *} \\
(-7.34)\end{array}$ & $\begin{array}{c}-0.39 \mathrm{E}-02 \\
(-0.69)\end{array}$ & $\begin{array}{c}-0.10^{* * *} \\
(-7.13)\end{array}$ & $\begin{array}{c}-0.35 \mathrm{E}-02 \\
(-0.59)\end{array}$ & $\begin{array}{c}-0.08 * * * \\
(-5.82)\end{array}$ & $\begin{array}{c}-0.79 \mathrm{E}-03 \\
(-0.15)\end{array}$ \\
\hline FDI & $\begin{array}{c}0.74 \\
(0.75)\end{array}$ & $\begin{array}{c}-0.18 \\
(-0.60)\end{array}$ & $\begin{array}{c}1.51 \\
(1.61)\end{array}$ & $\begin{array}{c}-0.14 \\
(-0.47)\end{array}$ & $\begin{array}{c}1.50 \\
(1.44)\end{array}$ & $\begin{array}{l}-0.17 \\
(-0.55)\end{array}$ \\
\hline TRADE & $\begin{array}{c}-0.91 * * * \\
(-4.01)\end{array}$ & $\begin{array}{l}-0.17^{* *} \\
(-1.97)\end{array}$ & $\begin{array}{c}-1.18 * * * \\
(-4.32)\end{array}$ & $\begin{array}{l}-0.16^{*} \\
(-1.70)\end{array}$ & $\begin{array}{l}-0.57 * * \\
(-2.36)\end{array}$ & $\begin{array}{c}-0.13 \\
(-1.56)\end{array}$ \\
\hline DEFICIT & $\begin{array}{l}-0.03 \\
(-1.21)\end{array}$ & $\begin{array}{c}0.59 \mathrm{E}-02 \\
(0.96)\end{array}$ & $\begin{array}{c}-0.03 \\
(-1.11)\end{array}$ & $\begin{array}{c}0.98 \mathrm{E}-02 * \\
(1.66)\end{array}$ & $\begin{array}{c}-0.04 \\
(-1.60)\end{array}$ & $\begin{array}{c}0.55 \mathrm{E}-02 \\
(0.89)\end{array}$ \\
\hline RIGHT & $\begin{array}{l}-0.27 * \\
(-1.63)\end{array}$ & $\begin{array}{c}-0.13^{* * *} \\
(2.98)\end{array}$ & $\begin{array}{l}-0.36^{* *} \\
(-2.14)\end{array}$ & $\begin{array}{c}-0.13 * * * \\
(-3.22)\end{array}$ & $\begin{array}{l}-0.38^{* *} \\
(-1.94)\end{array}$ & $\begin{array}{l}-0.11^{* *} \\
(-2 . .35)\end{array}$ \\
\hline TLC & $\begin{array}{c}0.67 * * * \\
(2.80)\end{array}$ & $\begin{array}{c}0.14^{* * * *} \\
(2.53)\end{array}$ & $\begin{array}{c}0.72 * * * \\
(2.91)\end{array}$ & $\begin{array}{l}0.14^{* * *} \\
(2.37)\end{array}$ & $\begin{array}{c}0.83^{* * *} \\
(3.14)\end{array}$ & $\begin{array}{c}0.14^{* * * *} \\
(2.61)\end{array}$ \\
\hline FINANCE & $\begin{array}{l}-0.09 \\
(-0.44)\end{array}$ & $\begin{array}{c}-0.02 \\
(-0.39)\end{array}$ & $\begin{array}{l}-0.08 \\
(-0.40)\end{array}$ & $\begin{array}{c}-0.03 \\
(-0.56)\end{array}$ & $\begin{array}{c}-0.29 \\
(-1.37)\end{array}$ & $\begin{array}{c}-0.04 \\
(-0.73)\end{array}$ \\
\hline ENERGY & $\begin{array}{c}0.15 \\
(0.58)\end{array}$ & $\begin{array}{c}-0.10 \\
(-1.60)\end{array}$ & $\begin{array}{c}0.12 \\
(0.42)\end{array}$ & $\begin{array}{l}-0.11^{*} \\
(-1.83)\end{array}$ & $\begin{array}{c}0.28 \\
(0.95)\end{array}$ & $\begin{array}{l}-0.11^{*} \\
(-1.80)\end{array}$ \\
\hline UTILITY & $\begin{array}{l}0.15 \\
(0.67)\end{array}$ & $\begin{array}{c}-0.03 \\
(-0.50)\end{array}$ & $\begin{array}{c}-0.04 \\
(-0.16)\end{array}$ & $\begin{array}{c}-0.04 \\
(-0.80)\end{array}$ & $\begin{array}{c}0.01 \\
(0.06)\end{array}$ & $\begin{array}{c}-0.03 \\
(-0.60)\end{array}$ \\
\hline IPO & $\begin{array}{c}-0.46^{* * * *} \\
(-2.82)\end{array}$ & $\begin{array}{c}-0.11 * * * \\
(-2.81)\end{array}$ & $\begin{array}{l}-0.29 * \\
(-1.68)\end{array}$ & $\begin{array}{c}-0.09 * * * \\
(-2.48)\end{array}$ & $\begin{array}{c}-0.11 \\
(-0.59)\end{array}$ & $\begin{array}{c}-0.09 * * \\
(-2.21)\end{array}$ \\
\hline TIME & & & $\begin{array}{c}0.01 * * * * \\
(5.20)\end{array}$ & $\begin{array}{c}-0.11 \mathrm{E}-03 \\
(-0.24)\end{array}$ & $\begin{array}{c}0.01 \text { *** } \\
(6.66)\end{array}$ & $\begin{array}{c}0.41 \mathrm{E}-03 \\
(0.76)\end{array}$ \\
\hline CAP & $0.46 \mathrm{E}-02$ & $-0.64 \mathrm{E}-03$ & & & & \\
\hline
\end{tabular}




\begin{tabular}{|c|c|c|c|c|c|c|}
\hline & $(1.56)$ & $(-0.84)$ & & & & \\
\hline FLOAT & & & $\begin{array}{c}0.45 \mathrm{E}-02 * * \\
(2.35)\end{array}$ & $\begin{array}{c}0.30 \mathrm{E}-03 \\
(0.42)\end{array}$ & & \\
\hline ANTID & & & & & $\begin{array}{c}-0.20 * * \\
(-2.23)\end{array}$ & $\begin{array}{c}-0.04 * * \\
(-2.33)\end{array}$ \\
\hline CREDITOR & & & & & $\begin{array}{c}-0.31 * * * \\
(-4.40)\end{array}$ & $\begin{array}{c}-0.02 \\
(-0.98)\end{array}$ \\
\hline \multirow[t]{2}{*}{$\sigma$} & $0.26 * * *$ & & & $0.24 * * *$ & & $0.24 * * *$ \\
\hline & $(12.01)$ & & & (11.85) & & (13.55) \\
\hline \multirow[t]{2}{*}{$\rho$} & $0.83^{* * *}$ & & & $0.74 * * *$ & & $0.78^{* * *}$ \\
\hline & $(9.63)$ & & & $(5.51)$ & & (8.17) \\
\hline LogLikelihood & & -165.65 & & -144.69 & & -133.60 \\
\hline Nobs: & & 382 & & 381 & & 383 \\
\hline
\end{tabular}

NOTE - * Statistically significant at the $10 \%$ level; ** Statistically significant at the $5 \%$ level; *** Statistically significant at the $1 \%$ level. $\mathrm{t}$-statistics in brackets; standard errors are computed using the Newton algorithm (analytic second derivatives) 
Table 7: The decision to sell abroad and stake sold on international markets: Sample selection estimation (OECD sample)

\begin{tabular}{|c|c|c|c|c|c|c|c|c|}
\hline & $\begin{array}{l}\text { PROBIT } \\
\text { EQUATION }\end{array}$ & $\begin{array}{l}\text { REGRESSIO } \\
\text { N EQUATION }\end{array}$ & $\begin{array}{l}\text { PROBIT } \\
\text { EQUATION }\end{array}$ & $\begin{array}{l}\text { REGRESSIO } \\
\text { N EQUATION }\end{array}$ & $\begin{array}{l}\text { PROBIT } \\
\text { EQUATION }\end{array}$ & $\begin{array}{l}\text { REGRESSIO } \\
\text { N EQUATION }\end{array}$ & $\begin{array}{l}\text { PROBIT } \\
\text { EQUATION }\end{array}$ & $\begin{array}{l}\text { REGRESSIO } \\
\text { N EQUATION }\end{array}$ \\
\hline \multirow[t]{2}{*}{ CONSTANT } & $-1.39 * * *$ & $0.38^{* * *}$ & -0.24 & $0.56^{\text {**** }}$ & $-1.62 * * *$ & $0.29^{* * *}$ & -0.75 & $0.64^{* * *}$ \\
\hline & $(-2.72)$ & $(7.82)$ & $(-0.66)$ & (13.71) & $(-3.07)$ & (3.73) & $(-1.36)$ & (13.18) \\
\hline \multirow{2}{*}{ PILPRO } & $0.11 \mathrm{E}-03^{* * *}$ & & $0.78 \mathrm{E}-04 * * *$ & & $0.80 \mathrm{E}-04 * * *$ & & $0.11 \mathrm{E}-03 * * *$ & \\
\hline & $(4.00)$ & & (3.19) & & $(2.52)$ & & (3.97) & \\
\hline \multirow[t]{2}{*}{ FDI } & $16.32 * *$ & 0.85 & 4.52 & 0.72 & $15.80^{* *}$ & 0.93 & $18.62 * *$ & 1.10 \\
\hline & (2.16) & $(0.83)$ & $(0.72)$ & $(0.67)$ & $(2.03)$ & $(0.90)$ & $(2.33)$ & (1.05) \\
\hline \multirow[t]{2}{*}{ UNEMP } & $-1.34 * * *$ & $-0.14 *$ & $-1.53 * * *$ & -0.08 & $-1.01 * * *$ & $-0.14 *$ & $-1.27 * * *$ & -0.12 \\
\hline & $(-3.65)$ & $(-1.71)$ & $(-4.36)$ & $(-0.99)$ & $(-2.52)$ & $(-1.79)$ & $(-3.52)$ & $(-1.53)$ \\
\hline \multirow[t]{2}{*}{ DEFICIT } & $-0.61 \mathrm{E}-03$ & $0.02 * * *$ & & & 0.01 & $0.02^{* * * *}$ & & \\
\hline & $(-0.01)$ & $(0.61 \mathrm{E}-02)$ & & & $(0.29)$ & $(3.25)$ & & \\
\hline \multirow{2}{*}{ RIGHT } & $-0.90 * * *$ & $-0.08 * *$ & $-0.68 * * *$ & & $-0.75 * * *$ & $-0.07 *$ & & \\
\hline & $(-3.88)$ & $(-2.18)$ & $(-3.12)$ & & $(-3.16)$ & $(-1.81)$ & & \\
\hline \multirow[t]{2}{*}{ TLC } & 0.47 & & 0.44 & & 0.42 & & 0.57 & \\
\hline & (1.28) & & (1.36) & & (1.18) & & (1.54) & \\
\hline \multirow[t]{2}{*}{ IPO } & -0.09 & $-0.06^{*}$ & -0.30 & $-0.08^{* *}$ & -0.08 & $-0.06^{*}$ & -0.14 & $-0.08^{* *}$ \\
\hline & $(-0.39)$ & $(-1.70)$ & $(-1.45)$ & $(-2.04)$ & $(-0.31)$ & $(-1.77)$ & $(-0.62)$ & $(-2.19)$ \\
\hline \multirow[t]{2}{*}{ TIME } & $0.02 * * *$ & & & & $0.01 * * *$ & & $0.02 * * *$ & \\
\hline & $(6.20)$ & & & & $(5.28)$ & & $(6.13)$ & \\
\hline \multirow[t]{3}{*}{ CAP } & & & $0.01 * * *$ & $-0.22 \mathrm{E}-$ & & & & \\
\hline & & & & $02 * * *$ & & & & \\
\hline & & & (3.03) & $(-3.72)$ & & & & \\
\hline \multirow[t]{2}{*}{ FLOAT } & & & & & $0.01 * * *$ & $0.13 \mathrm{E}-02$ & & \\
\hline & & & & & $(2.74)$ & $(1.43)$ & & \\
\hline \multirow[t]{2}{*}{ ANTID } & & & & & & & $-0.36 * * *$ & $-0.04 * * *$ \\
\hline & & & & & & & $(-3.27)$ & $(-3.42)$ \\
\hline \multirow[t]{2}{*}{ CREDITOR } & & & & & & & 0.01 & $-0.02 *$ \\
\hline & & & & & & & $(0.12)$ & $(-1.67)$ \\
\hline$\sigma$ & $0.20 * * *$ & & $0.20 * * *$ & & $0.20^{* * *}$ & & $0.20^{* * *}$ & \\
\hline
\end{tabular}




\begin{tabular}{|c|c|c|c|c|}
\hline$\rho$ & $\begin{array}{c}(15.62) \\
0.29 \\
(1.03)\end{array}$ & $\begin{array}{c}(14.55) \\
-0.30 \\
(-1.16)\end{array}$ & $\begin{array}{c}(13.75) \\
0.45 \\
(1.50)\end{array}$ & $\begin{array}{c}(17.14) \\
0.01 \\
(0.06)\end{array}$ \\
\hline \begin{tabular}{|l} 
LogLikeliho \\
od
\end{tabular} & -61.45 & -87.63 & -57.01 & -65.45 \\
\hline Nobs: & 213 & 216 & 213 & 216 \\
\hline
\end{tabular}

NOTE - * Statistically significant at the $10 \%$ level; ** Statistically significant at the $5 \%$ level; *** Statistically significant at the $1 \%$ level. $\mathrm{t}$-statistics in brackets; standard errors are computed using the Newton algorithm (analytic second derivatives) 
Table 8: The decision to sell abroad and stake sold on international markets: Sample selection estimation (non-OECD sample)

\begin{tabular}{|c|c|c|c|c|c|c|c|c|c|c|}
\hline & $\begin{array}{r}\text { PROB } \\
\text { IT EQUATION }\end{array}$ & $\begin{array}{c}\text { REGRE } \\
\text { SSION } \\
\text { EQUATION }\end{array}$ & $\begin{array}{l}\text { PROBIT } \\
\text { EQUATION }\end{array}$ & $\begin{array}{c}\text { REGRE } \\
\text { SSION } \\
\text { EQUATION }\end{array}$ & $\begin{array}{l}\text { PROBIT } \\
\text { EQUATION }\end{array}$ & $\begin{array}{c}\text { REGRE } \\
\text { SSION } \\
\text { EQUATION }\end{array}$ & $\begin{array}{l}\text { PROBIT } \\
\text { EQUATION }\end{array}$ & $\begin{array}{c}\text { REGRE } \\
\text { SSION } \\
\text { EQUATION }\end{array}$ & $\begin{array}{l}\text { PROBIT } \\
\text { EQUATION }\end{array}$ & $\begin{array}{c}\text { REGRE } \\
\text { SSION } \\
\text { EQUATION }\end{array}$ \\
\hline CONSTANT & \begin{tabular}{r}
\multicolumn{1}{c}{-} \\
$1.98 * * *$ \\
$(-3.24)$
\end{tabular} & $\begin{array}{l}1.65^{* * * *} \\
(5.35)\end{array}$ & $\begin{array}{l}-1.29 * * \\
(-1.92)\end{array}$ & $\begin{array}{l}1.43^{* * * *} \\
(5.95)\end{array}$ & $\begin{array}{l}-0.57 \\
(-0.91)\end{array}$ & $\begin{array}{l}1.36^{* * * *} \\
(5.10)\end{array}$ & $\begin{array}{l}-0.63 \\
(-0.99)\end{array}$ & $\begin{array}{c}1.26^{* * * *} \\
(4.72)\end{array}$ & $\begin{array}{l}1.13^{*} \\
(1.91)\end{array}$ & $\begin{array}{c}0.60 * * * \\
(3.64)\end{array}$ \\
\hline FDI & $\begin{array}{c}0.79 \\
(0.81)\end{array}$ & $\begin{array}{c}-0.84 * * * \\
(-2.57)\end{array}$ & $\begin{array}{l}0.22 \\
(0.18)\end{array}$ & $\begin{array}{c}-0.83^{* * *} \\
(-2.71)\end{array}$ & & & & & $\begin{array}{c}0.2 \\
(0.40)\end{array}$ & $\begin{array}{l}-0.75^{* *} \\
(-2.02)\end{array}$ \\
\hline FDEBT & & & $\begin{array}{c}-1.84 * * * \\
(-4.12)\end{array}$ & $\begin{array}{l}0.10 \\
(0.46)\end{array}$ & $\begin{array}{c}-1.77 * * * \\
(-3.89)\end{array}$ & $\begin{array}{c}0.40 \\
(1.37)\end{array}$ & $\begin{array}{c}-2.11 * * * \\
(-3.84)\end{array}$ & $\begin{array}{l}0.30 \\
(1.08)\end{array}$ & $\begin{array}{c}-1.35 * * * \\
(-2.86)\end{array}$ & $\begin{array}{c}0.36 \\
(1.60)\end{array}$ \\
\hline DEFICIT & $\begin{array}{l}-0.03 \\
(-0.97)\end{array}$ & $\begin{array}{c}0.20 \mathrm{E}-03 \\
(0.01)\end{array}$ & & & & & & & & \\
\hline RIGHT & $\begin{array}{l}0.92 * * \\
* \\
(3.31)\end{array}$ & $\begin{array}{c}-0.37 * * * \\
(-3.99)\end{array}$ & $\begin{array}{l}0.98 * * * \\
(2.84)\end{array}$ & $\begin{array}{l}-0.36 * * * \\
(-4.11)\end{array}$ & $\begin{array}{l}0.74 * * \\
(2.22)\end{array}$ & $\begin{array}{c}-0.43 * * * \\
(-3.05)\end{array}$ & $\begin{array}{l}0.76^{* * *} \\
(2.22)\end{array}$ & $\begin{array}{l}-0.35 * * * \\
(-2.98)\end{array}$ & & \\
\hline CREDIB & $\begin{array}{c}0.05 \\
(0.79)\end{array}$ & $\begin{array}{c}-0.06^{* *} \\
(-2.18)\end{array}$ & $\begin{array}{c}0.10 \\
(1.37)\end{array}$ & $\begin{array}{l}-0.05^{*} \\
(-1.79)\end{array}$ & $\begin{array}{c}0.11 \\
(1.56)\end{array}$ & $\begin{array}{l}-0.05 \\
(-1.58)\end{array}$ & $\begin{array}{l}0.13^{*} \\
(1.79)\end{array}$ & $\begin{array}{l}-0.05^{*} \\
(-1.64)\end{array}$ & & \\
\hline TLC & $\begin{array}{l}1.30 * * \\
* \\
(4.09)\end{array}$ & & $\begin{array}{l}1.14 * * * \\
(3.24)\end{array}$ & & $\begin{array}{l}0.89 * * \\
(2.09)\end{array}$ & & $\begin{array}{l}1.09 * * * \\
(2.99)\end{array}$ & & $\begin{array}{l}0.92 * * * \\
(2.75)\end{array}$ & \\
\hline TIME & $0.01 * *$ & $\begin{array}{l}-0.56 \mathrm{E}- \\
02 * * *\end{array}$ & $0.01 * * *$ & $\begin{array}{l}-0.56 \mathrm{E}- \\
02 * * *\end{array}$ & & & & & $0.02^{* * *}$ & $\begin{array}{l}-0.74 \mathrm{E}- \\
02 * * *\end{array}$ \\
\hline CAP & $(2.36)$ & $(-4.45)$ & (2.87) & $(-4.40)$ & $\begin{array}{l}-0.67 \mathrm{E}- \\
02 \\
\quad(-1.01)\end{array}$ & $\begin{array}{l}-0.42 \mathrm{E}- \\
02 \\
(-1.55)\end{array}$ & & & (3.40) & $(-4.27)$ \\
\hline FLOAT & & & & & & & $\begin{array}{l}-0.76 \mathrm{E}- \\
02 * *\end{array}$ & $\begin{array}{l}-0.17 \mathrm{E}- \\
02\end{array}$ & & \\
\hline
\end{tabular}




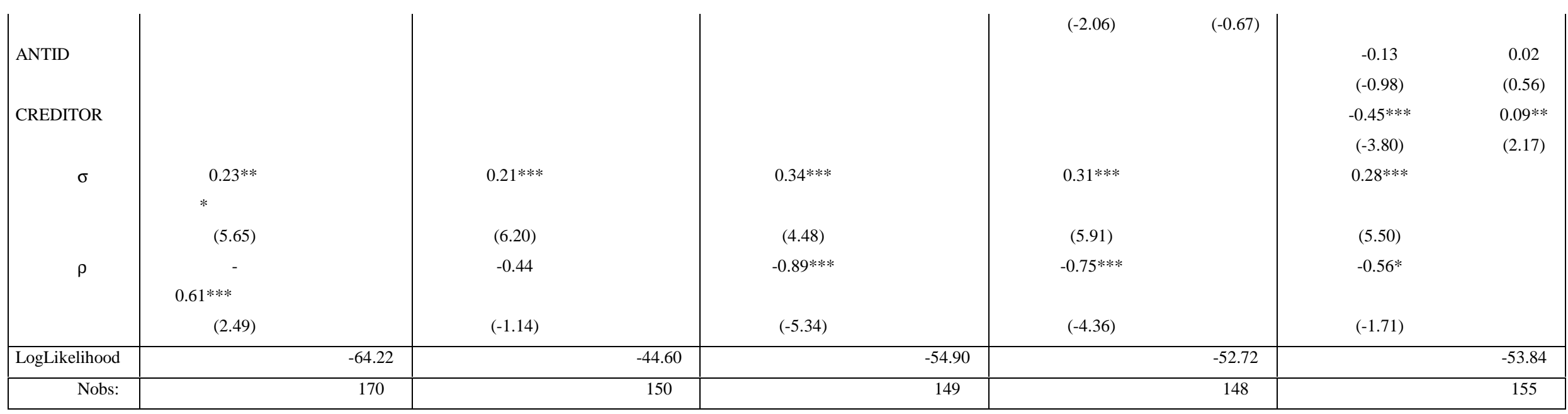

NOTE - * Statistically significant at the $10 \%$ level; $* *$ Statistically significant at the $5 \%$ level; $* * *$ Statistically significant at the $1 \%$ level. t-statistics in brackets; standard errors are computed using the Newton algorithm (analytic second derivatives) 